This item was submitted to Loughborough's Research Repository by the author.

Items in Figshare are protected by copyright, with all rights reserved, unless otherwise indicated.

\title{
Phosphorescent molecular metal complexes in heterojunction solar cells
}

PLEASE CITE THE PUBLISHED VERSION

https://doi.org/10.1016/j.poly.2017.11.050

PUBLISHER

(c) Elsevier Ltd

VERSION

AM (Accepted Manuscript)

PUBLISHER STATEMENT

This work is made available according to the conditions of the Creative Commons Attribution-NonCommercialNoDerivatives 4.0 International (CC BY-NC-ND 4.0) licence. Full details of this licence are available at: https://creativecommons.org/licenses/by-nc-nd/4.0/

\section{LICENCE}

CC BY-NC-ND 4.0

\section{REPOSITORY RECORD}

Wright, lain. 2019. "Phosphorescent Molecular Metal Complexes in Heterojunction Solar Cells". figshare. https://hdl.handle.net/2134/28046. 


\title{
Phosphorescent Molecular Metal Complexes in Heterojunction
}

\section{Solar Cells}

\author{
lain A. Wright* \\ Department of Chemistry, Loughborough University, Epinal Way, LE11 3TU, United Kingdom \\ Corresponding author at: Department of Chemistry, Loughborough University, Epinal Way, LE11 3TU, United \\ Kingdom. \\ E-mail address: i.a.wright@lboro.ac.uk
}

\section{Keywords}

organic solar cells, triplet sensitizer, phosphorescent metal complexes, energy transfer, bulk heterojunction

\begin{abstract}
Bulk heterojunction (BHJ) solar cells have been developed intensively over the last two decades due to the cheap, flexible devices which may be obtained although their efficiency is below that of other emerging solar cell technologies such as dye-sensitized and perovskite solar cells. Molecular organometallic phosphors are noted for their triplet harvesting ability which has produced highly efficient organic light-emitting devices however triplet harvesting presents an equally appealing route to improve the efficiency of BHJ devices. The results of studies using molecular phosphors as dopants in very small loadings can yield large increases in short circuit currents and power conversion efficiency and demonstrate that improvements in solar cell performance may be obtained by this approach.
\end{abstract}

\section{Introduction}

Bulk-heterojunction (BHJ) solar cells are an emerging technology for solar energy conversion alongside dye-sensitized solar cells (DSSCs) and perovskite solar cells. Polypyridyl complexes of heavy transition metals such as ruthenium[1-11] and, more recently, of cobalt,[12-22] copper,[23-32] zinc $[33,34]$ and other earth-abundant $3 d$ elements $[35,36]$ are closely associated with DSSC technology while the best performing perovskite devices also rely upon heavy atoms such as tin and lead.[37-42] The development of materials suitable for BHJ devices has focused much more closely on purely organic systems.

BHJ devices utilize an electron donating material, typically an electronically delocalized oligomer[4352] or conjugated polymer[48,50,53-61] blended with an electron accepting small molecule. While there are a large number of studied donor materials the electron acceptor is often a fullerene such as $\mathrm{C}_{60}, \mathrm{C}_{70}, \mathrm{PC}_{61} \mathrm{BM}$ or $\mathrm{PC}_{71} \mathrm{BM}$ (figure 1) $[50,62,63]$ although in recent years studies using non- 
fullerene acceptors such as perylene diimide derivatives or other organic molecules capable of forming stable anions have increased in profile.[64-66] The blended nature of the BHJ results in an interpenetrated network of the donor and acceptor species which provides a very large interfacial area between these components. As the charge transfer required for device operation occurs at these interfaces, the $\mathrm{BHJ}$ improves charge carrier generation and transport and overcomes the limitations imposed by earlier bilayer (BL) devices where the heterojunction consisted simply of stacked layers of donor and acceptor.[53,67-69] Some basic differences between these device architectures alongside that of a doped ternary BHJ device are shown in scheme 1.

\section{Figure 1}

\section{Scheme 1}

Here, the use of molecular metal complexes in $\mathrm{BHJ}$ and related $\mathrm{BL}$ devices will be presented in order to demonstrate the large extent to which the use of high triplet yield organometallics can improve organic solar cell (OSC) performance, particularly when used as dopants. The doped devices are an example of ternary $\mathrm{BHJ}$ devices whereby a third component helps to improve one or more device parameters. Ternary cells are among the most promising technologies under development and have led to BHJ efficiencies exceeding $10 \%$.[70-73]

While detailed explanations of the operating principles of BHJ devices are available elsewhere,[7478] a basic representation of these processes and associated energy levels are shown in scheme 2 . The donor undergoes photoexcitation prior to charge transfer to an acceptor molecule. This results in the formation of a transient polaron pair which consists of the electrostatically bound donor radical cation and acceptor radical anion. Dissociation of this polaron pair, in competition with geminate recombination back to the ground state, gives rise to free charge carriers which can migrate towards the electrodes and thus an electrical current is generated.

\section{Scheme 2}

The primary indicators of cell performance which will be considered here are the short circuit current density $\left(J_{s c}\right)$, open circuit voltage $\left(V_{o c}\right)$, fill factor $(F F)$ and quantum efficiency $(\eta)$. The first three factors are related to $\eta$ according to equation 1 where $P_{0}$ is the power of the incident light on the device, typically the AM1.5 solar spectrum at $100 \mathrm{~mW} \mathrm{~cm}^{-2}$.

$$
\eta=\frac{J_{S C} V_{O C} F F}{P_{0}}
$$

A common postulation in the studies presented here is that by incorporating complexes of heavy transition metals the photogenerated triplet yield will increase due to the spin-orbit coupling associated with high atomic weight elements. Spin-orbit coupling converts singlet excitons to formally forbidden triplet excitons by intersystem crossing (ISC).[79] This approach may be 
considered complementary to the use of phosphorescent complexes in organic light emitting devices.[80-82]

As triplet excitons in an organic material will typically have a much longer lifetime than singlet excitons, an increased exciton diffusion length $\left(L_{D}\right)$ accompanied with a decrease in recombination will occur in phosphor sensitized OSCs primarily resulting in a greatly improved $J_{s c}$. Similar logic is employed in the development of singlet fission based organic solar cells where one singlet exciton shares energy with the singlet ground state to produce two triplet states of intermediate energy which then take part in generating the photocurrent. [78,83-85] However, singlet fission relies on the energy of the first excited triplet state to be approximately half that of the singlet exciton which is a challenging criteria to satisfy and results in lower energy excitons which can limit the attainable $V_{o c} \cdot[78,86]$

Although care must be taken to ensure that the frontier orbital energy levels of the dopant will not have a negative impact on photovoltaic performance, such as introducing energetically favourable deactivation pathways or otherwise limiting $V_{o c}$, phosphorescent metal complexes can be implemented as dopants quite easily and alongside their ability to improve $L_{D}$ and $J_{s c}$ the metalligand charge transfer (MLCT) and related charge transfer processes characteristic of these complexes can also help to improve absorption of sunlight.

\section{Scheme 3}

Energy transfer processes taking place within the triplet sensitized heterojunction including short range Dexter electron transfer where an electron hops from one molecule to another and longer range Förster resonance energy transfer (FRET) where the energy released upon relaxation of a first molecule in an excited state transfers non-radiatively to generate an excited state in a second molecule.[78,85,87-89] Both of these processes are shown in scheme 3. FRET functions very well as a singlet transfer mechanism while Dexter transfer is far more efficient at transporting triplets. [90] Increases in triplet yield and $L_{D}$ have been definitively confirmed in phosphor doped organics $[87,91,92]$ however precise mechanisms for the energy transfer processes taking place within a triplet sensitized $\mathrm{BHJ}$ are challenging to identify and it seems likely that both transfer mechanisms are able to contribute to the improved performance.

A focus on discrete molecular complexes will be maintained, readers specifically interested in the use of metal containing polymers are directed to relevant literature.[93-96] Studies of complexes of a range of metals will be presented and are organized according to their group in the periodic table. As a further note, the reader is advised that device performance in all organic photovoltaic technologies improved rapidly over the last 15 years due to improved device fabrication as much as 
to the synthesis of new materials, therefore a sense of perspective should be maintained when evaluating early studies. $[78,97,98]$

\section{Phosphors used in BHJs}

\subsection{Group 7}

\section{Rhenium}

\section{Figure 2}

Rhenium(I) tricarbonyl $\alpha$-diimine complexes 1 (figure 2 ) with the general formula fac- $\left[\operatorname{Re}(\mathrm{X})(\mathrm{CO})_{3}(\alpha\right.$ diimine)] (where $X=$ halide/pseudo-halide) have long-lived and ligand tunable excited states and electrochemical properties allowing them to effectively harvest solar wavelengths and convert absorbed light into useful energy.[99,100] As the structure of the $\alpha$-diimine ligand is known to have a strong influence on the MLCT properties of these complexes this is a relatively straightforward property to control. These complexes are easy to synthesize and provide some of the earliest insights into the use of molecular metal complexes in OSCs.

In 2001, the group of Chan produced a series of $f a c-\left[\operatorname{Re}(C l)(C O)_{3}(D A B)\right](D A B=1,4$-diazabutadiene) photosensitizers 2a-e (fig. 2) which displayed very low photoconductivity $\left(\sigma \approx 10^{-14} \Omega^{-1} \mathrm{~cm}^{-1}\right)$ when blended into a poly(carbonate) host attributed to poor charge carrier mobility.[101] However, when added as a dopant to a blend of the hole transporting material (HTM) triphenylamine in poly(carbonate) the photoconductivity increased by up to five orders of magnitude ( $2 \mathrm{~d}, \sigma=1.3 \times 10^{-9}$ $\left.\Omega^{-1} \mathrm{~cm}^{-1}\right)$. Complex $2 \mathbf{d}$ was incorporated into a BL solar cell with $\mathrm{C}_{60}$ as the acceptor producing a maximum open circuit voltage $V_{o c}=0.38 \mathrm{~V}, \mathrm{FF}=0.18$ and an efficiency of $2 \%$ under illumination at $460 \mathrm{~nm}$ and $1.9 \mathrm{~mW} \mathrm{~cm}^{-2} .[101,102]$

Subsequent investigations utilized $f a c-\left[\operatorname{Re}(\mathrm{Cl})(\mathrm{CO})_{3}(\mathrm{DIAN})\right](\mathrm{DIAN}=$ bis(phenylimino)acenaphthene) complexes 3a-h (fig. 2) in vacuum deposited $B L$ and $B H J$ devices using $\mathrm{C}_{60}$ as acceptor alongside copper phthalocyanine ( $\mathrm{CuPc}$ ) and $\mathrm{C}_{60}$ as hole and electron transport layers respectively. [103-105] Studies of 3a demonstrated that it is ambipolar with good electron and hole mobilities of $\mu=2.5 \times$ $10^{-3}$ and $2.3 \times 10^{-3} \mathrm{~cm}^{2} \mathrm{~V}^{-1} \mathrm{~s}^{-1}$ respectively, which should enhance charge transport behavior. A BL device using 3a demonstrated a $V_{o c}=0.58 \mathrm{~V}, J_{s c}=0.18 \mathrm{~mA} \mathrm{~cm}{ }^{-2}$, and $\mathrm{FF}=0.28$ giving only $\eta=0.03 \%$. However by manufacturing the device as a $\mathrm{BHJ}$ through co-sublimation of $\mathbf{3 a}$ and $\mathrm{C}_{60}$ in a 1:1 ratio the performance improved drastically with $V_{o c}=0.45 \mathrm{~V}, J_{s c}=1.9 \mathrm{~mA} \mathrm{~cm}{ }^{-2}, \mathrm{FF}=0.56$ and $\eta=$ 0.48\%.[103] Ultimately, by optimizing device construction through control of heterojunction thickness, ratio of $3 a$ to $C_{60}$ and choice of $H T M$, devices were obtained with a $V_{o c}=0.51 \mathrm{~V}, J_{s c}=5.07$ $\mathrm{mA} \mathrm{cm}{ }^{-2}, \mathrm{FF}=0.51$ and $\eta=1.29 \%$, an almost threefold improvement.[104,105] 
In $2008 \mathrm{Ma}$ et al. reported the oligo(phenylenevinylene) cruciform 4 centered around a $\left[\operatorname{Re}(\mathrm{Cl})(\mathrm{CO})_{3}(\mathrm{bpy})\right]\left(\mathrm{bpy}=2,2^{\prime}\right.$-bipyridine) moiety (fig. 2).[106] The authors postulate that the oligomer arms and rhenium $\alpha$-diimine core could function as donor and acceptor respectively, so a single layer device of the complex was produced alongside a $\mathrm{BHJ}$ device with $\mathrm{PC}_{61} \mathrm{BM}$ as the acceptor. The single layer devices performed poorly despite having a high $V_{o c}=0.72 \mathrm{~V}$ due to a low $J_{s c}=0.082 \mathrm{~mA} \mathrm{~cm}^{-2}$ and $\mathrm{FF}=0.21$ giving $\eta=0.012 \%$. The BHJ devices were more functional, displaying $V_{o c}=0.75 \mathrm{~V}, \mathrm{~J}_{s c}=3.8 \mathrm{~mA} \mathrm{~cm}{ }^{-2}$ and $\mathrm{FF}=0.28$ giving $\eta=0.8 \%$. The presence of the Re atom in $\mathbf{4}$ did show improved performance compared to the uncoordinated ligand.

While a number of other $\operatorname{Re}(\mathrm{I})$ tricarbonyl complexes have since been prepared displaying properties such as triplet-triplet annihilation and have been identified as useful triplet photosensitizers, these molecules have not been further employed in OSC devices.[107,108]

\subsection{Group 8}

\section{Ruthenium}

Figure 3

In 2004, dimeric ruthenium phthalocyanine $[\mathrm{RuPc}]_{2}$ was employed in a $\mathrm{BL}$ device with $\mathrm{C}_{60}$ displaying $J_{s c}=0.23 \mathrm{~mA} \mathrm{~cm}^{-2}$ and $V_{o c}=0.17 \mathrm{~V}$ although its EQE responses showed a marked sensitivity to air.[109]

In a collaborative study in 2009, dendritic oligothiophene functionalized RuPc derivatives 5-10 (figure 3) were prepared and utilized in solution processed BHJ devices.[110] These complexes displayed strong absorbance across the UV-vis region with the magnitude of absorptivity increasing with thiophene content. However, it was complexes $\mathbf{5}$ and $\mathbf{8}$ containing Py-3T which produced the best devices with higher $J_{s c}$ values making up for losses in $V_{o c}$ when compared to the larger analogues. These complexes blended well with $\mathrm{PC}_{61} \mathrm{BM}$ resulting in smooth films as measured by atomic force microscopy (AFM). $\mathbf{5}$ and $\mathbf{8}$ displayed notably improved performance when the less symmetric fullerene $\mathrm{PC}_{71} \mathrm{BM}$ was used in place of $\mathrm{PC}_{61} \mathrm{BM}$ (table 1). Ultimately 8: $\mathrm{PC}_{71} \mathrm{BM}$ produced the best OSCs overall with $V_{o c}=0.56 \mathrm{~V}, \mathrm{~J}_{s c}=8.3 \mathrm{~mA} \mathrm{~cm}{ }^{-2}, \mathrm{FF}=0.34$ and $\eta=1.6 \%$. All of the complexes outperformed an oligothiophene free analogue $\left(\mathbf{L}=\mathbf{L}^{\prime}=\right.$ pyridine $)$. An interesting trend observed for these complexes is that the $V_{o c}$ tends to increase with increasing thiophene content which is surprising considering that the HOMO levels for the complexes are identical therefore this must indicate some further influence of the oligothiophene chains.

\section{Table 1}

Researchers in Milan incorporated the diruthenium bis(acetylide) complex $\mathbf{1 1}$ (fig. 3) in BHJ devices with $\mathrm{PC}_{61} \mathrm{BM}$.[111] Photoexcited charge transfer between 11 and $\mathrm{PC}_{61} \mathrm{BM}$ was established however 
short circuit currents were low $J_{s c}=0.66 \mathrm{~mA} \mathrm{~cm}^{-2}$ and only $\eta=0.08 \%$ was obtained. The low $J_{s c}$ values bis(acetylide) complexes were reported by Liu et al. and showed comparable performance in BHJ devices with $\mathrm{PC}_{71} \mathrm{BM}$.[112] The best performing device consisted of 12: $\mathrm{PC}_{71} \mathrm{BM}$ in a ratio of 1:4 displaying $V_{o c}=0.51 \mathrm{~V}, J_{s c}=4.24 \mathrm{~mA} \mathrm{~cm}{ }^{-2}, \mathrm{FF}=0.31$ and $\eta=0.66 \%$. The other members of the series had one or more triphenylamine groups bound to the terminal thiophene but did not perform well in OSCs.

Azadipyrromethene complexes 13-15 (fig. 3) were reported by Bessette et al. and their properties discussed in the context of photosensitizers for OSCs but no actually device performance was reported.[113]

\subsection{Group 9}

\section{Iridium Complexes as Dopants}

The majority of studies of molecular Ir(III) complexes in OSCs primarily use them as dopants or interlayers for existing conjugated polymer donors and significant improvements in device properties can be observed when the complexes are employed in this way.

\section{Figure 4}

Yang et al. doped end-capped poly(fluorene) (PFO) with $\operatorname{Ir}(\mathrm{mppy})_{3} \mathbf{1 6}$ (figure 4) and identified a large increase in triplet exciton population.[114] They then made OSCs using blends of PFO and P3HT (fig. 4) with CdSe nanocrystals. Doping of these OSCs with 16 at a loading of 10 wt\% caused a $200 \%$ increase in $\mathrm{J}_{s c}$ for PFO and $100 \%$ increase for P3HT indicating that the presence of the phosphorescent dopant yielded more, long-lived charge carriers. For PFO a $50 \%$ increase in $V_{o c}$ was also observed.

In a detailed study in 2008 the groups of Howe and Hu noted an $80 \%$ increase in $\eta$ by doping 5 wt $\%$ $\operatorname{Ir}(\text { ppy })_{3} 17$ (fig. 4) into an MEH-PPV/PC ${ }_{61}$ BM. The dopant improved the $J_{s c}$ from 0.6 to $1.1 \mathrm{~mA} \mathrm{~cm}^{-2}$ under illumination of $8 \mathrm{~mW} \mathrm{~cm}^{-2}$ at $500 \mathrm{~nm}$ leading to the improved efficiency.[115] A similar $J_{s c}$ response was observed at wavelengths from 370 to $700 \mathrm{~nm}$. The $V_{o c}$ and FF were essentially unaffected at $0.82 \mathrm{~V}$ and 0.29 respectively. By substituting 17 with aluminium tris(hydroxyquinoline) $\left(\mathrm{Alq}_{3}\right)$ which has comparable HOMO and LUMO levels, no such increase was observed. The presence of the Ir complex was shown to increase $L_{D}$ from 3.5 to $6.0 \mathrm{~nm}$. The authors conclude that these changes are due to spin-orbit coupling populating the triplet manifold and minimizing recombination. 
Devices utilizing the small molecule donor NPD (fig. 4) doped with 5 wt\% 17 also demonstrated an $\mathrm{nm}$ to $11.8 \mathrm{~nm}$, again attributed to an increased triplet population.[116] In 2011, Winroth et al. optimized the loading of $\mathbf{1 7}$ into a BHJ of the archetypical donor and acceptor pairing $\mathrm{P} 3 \mathrm{HT}$ and $\mathrm{PC}_{61} \mathrm{BM}$. [117] At 5 wt\% 17 improved all device parameters including the $V_{\text {oc }}$ from 0.26 to $0.41 \mathrm{~V}$, the short circuit current from -4.64 to $-14.4 \mu \mathrm{A}$, FF from 0.34 to 0.47 and $\eta$ at $340 \mathrm{~nm}$ jumped from 0.825 to $9.48 \%$ however $\eta$ dropped slightly from 1.14 to $0.92 \%$ when measured at 600 $\mathrm{nm}$. This study identified that the dopant can perform a number of roles simultaneously including harvesting high energy photons and introducing extra heterojunctions for exciton dissociation. This work also identifed that the deterioration of performance at higher dopant levels is due to morphological changes induced by the metal complex inhibiting the packing of P3HT chains therefore doping levels must be carefully controlled.

\section{Figure 5}

Yu et al. reported on the effect of inserting a layer of the complex bis(2-(4-tert-butylphenyl) benzothiazolato- $N, C^{2}$ ) iridium (acetylacetonate) 18 (figure 5) between the donor and acceptor layers of a $\mathrm{BL}$ device of pentacene and $\mathrm{C}_{60}$.[118] This extra layer was labelled a multicharge separation (MCS) layer and increasing the thickness of this layer from 0 to $8 \mathrm{~nm}$ resulted in the $V_{\text {oc }}$ increasing from 0.325 to $0.488 \mathrm{~V}$ alongside a decrease in $J_{s c}$ from 10.72 to $5.88 \mathrm{~mA} \mathrm{~cm}^{-2}$. At an MCS film thickness of $1 \mathrm{~nm}$ the $\mathrm{FF}=0.48$ which ultimately provided the highest $\eta=1.85 \%$. Similar dependencies were observed when the non-phosphorescent complex CuPc was employed as the MCS although in this case an optimized MCS film thickness of $4 \mathrm{~nm}$ yielded $\eta=1.98 \%$. Yu performed a second study of devices consisting of CuPc as donor and $\mathrm{C}_{60}$ as acceptor with varying amounts of 18 doped into the CuPc layer.[119] The extent of doping was optimized to 25 wt\% with larger concentrations of $\mathbf{1 8}$ leading to deteriorated charge transport. Overall device performance improved marginally from $\eta=1.23 \%$ in the non-doped device to $\eta=1.42 \%$ in the 18 doped device due primarily to an increase in $J_{s c}$ from 6.48 to $8.23 \mathrm{~mA} \mathrm{~cm}^{-2}$ and the $L_{D}$ from 10 to $17.4 \mathrm{~nm}$, indicating improved triplet sensitization. When these studies are considered together it appears that the presence of the MCS layer seems merely to increase series resistance and recombination rates while diminishing any influence from the triplet sensitizer. Upon considering that charge transfer to form polaron pairs prior to charge separation occurs at the interface of donor and acceptor interface it is perhaps unsurprising that the MCS layer can be a hindrance therefore the strategy of distributing the complex as a dopant throughout the BHJ seems much more promising.

Wang and Zhang utilized iridium tris(2-(benzo[b]thiophen-2-yl)pyridine) $\mathbf{1 9}$ (fig. 5) to dope BHJ solar cells of $\mathrm{P} 3 \mathrm{HT}: \mathrm{PC}_{61} \mathrm{BM}$ and primarily examined the sensitivity of device performance to annealing 
temperature.[120] They concluded that an optimum annealing temperature exists for each dopant concentration above which performance decreases attributed to aggregation of the metal complex dopants disrupting film morphology.

The groups of Kim, Kwon and Hong utilized a somewhat complex device using the ionic iridium complex 20 (fig. 5) as a triplet-singlet energy donor in the presence of polyethylene oxide (PEO) in conjunction with the $\mathrm{BHJ}$ pairing of $\mathrm{P} 3 \mathrm{HT}: \mathrm{PC}_{61} \mathrm{BM}$.[121] They postulated that improved morphological properties will arise from the hydrophobic quinolone based ligand while the mobile $\mathrm{Na}^{+}$ions in PEO will minimize electrode energy barriers. While efficient energy transfer between 20 and $\mathrm{P} 3 \mathrm{HT}$ was identified, in practice the gains in device efficiency were modest with the best consisting of a blend of $\mathrm{P} 3 \mathrm{HT}: \mathrm{PC}_{61} \mathrm{BM}: 20: \mathrm{PEO}$ in the weight ratio of 1:0.8:0.01:0.01 and annealed at $150{ }^{\circ} \mathrm{C}$. High $J_{s c}$ of over $10 \mathrm{~mA} \mathrm{~cm}{ }^{-2}$ were observed however the FF of the devices deteriorated in the presence of 20. A noteworthy result from this study is that simply incorporating PEO itself in the absence of $\mathbf{2 0}$ actually gave rise to markedly increased $V_{o c} J_{s c}$, and $\mathrm{FF}$ in the non-doped, nonannealed $\mathrm{P} 3 \mathrm{HT}: \mathrm{PC}_{61} \mathrm{BM}$ BHJ.[121]

Yao et al. presented a study focused upon the influence of varying levels of tris(phenylpyrazole)iridium 21 as a dopant in $\mathrm{BHJ}$ devices consisting of $\mathrm{P} 3 \mathrm{HT}$ and the indene- $\mathrm{C}_{60}-$ bisadduct ICBA, the structure of which is shown in figure 5.[122] In the presence of $0.1 \mathrm{wt} \% \mathbf{2 1} \mathrm{V}_{o c}$ and FF values showed almost no variation going from $0.827 \mathrm{~V}$ and 0.65 when non-doped and $0.821 \mathrm{~V}$ and 0.63 after doping. However the presence of 21 did yield an increase in $J_{s c}$ from 10.09 to 11.76 $\mathrm{mA} \mathrm{cm}{ }^{-2}$ thereby a moderate improvement in $\eta$ from 5.41 to $6.08 \%$. Upon annealing at $150{ }^{\circ} \mathrm{C}$ the $J_{s c}$ of the doped device increased further to $12.40 \mathrm{~mA} \mathrm{~cm}^{-2}$ which ultimately provided $\eta=7.08 \%$. Femtosecond time-resolved photoluminescence spectra revealed that energy transfer with $\mathbf{2 1}$ increased the $L_{D}$ of the P3HT:ICBA blend from 1.35 to $1.53 \mathrm{~nm}$. The presence of $\mathbf{2 1}$ in the BHJ also resulted in smoother films while thermal studies in conjunction with AFM and secondary ion mass spectroscopy identified that the annealing temperature can be used to control the vertical distribution of the complexes in the heterojunction. Prior to annealing the complexes have settled towards the bottom of the active layer. As the annealing temperature increases the complexes migrate vertically through the $\mathrm{BHJ}$ eventually reaching an optimum distribution in which to assist charge generation and transport. Increasing the annealing temperature further has a detrimental effect on device performance as had been observed in other studies.[120]

\section{Figure 6}

An elegant example of how heavy metal complexes can be employed as dopants was presented by Qian et al. whereby trace amounts of the iridium complex 22 (figure 6) were "doped" into the high performance polymer PTB7 in very small quantities by Stille type copolymerization to produce the 
new metallopolymer 23.[123] By synthesizing batches of $\mathbf{2 3}$ with controlled levels of doping between 0 and $5 \%$ then incorporating these polymers into $\mathrm{BHJ}$ devices with $\mathrm{PC}_{71} \mathrm{BM}$ as acceptor they obtained cells with $V_{o c}=0.75 \mathrm{~V}, \mathrm{~J}_{s c}=18.14 \mathrm{~mA} \mathrm{~cm}{ }^{-2}, \mathrm{FF}=0.64$ and $\eta=8.71 \%$. Improvements in $\eta$ of up to $45 \%$ were observed compared to PTB7 at a dopant loading of $1 \%$. These improvements were primarily attributed to large increases in $J_{s c}$ and moderate increases in FF. Similarly to previous studies, further increasing the dopant concentration proved detrimental to performance and AFM imaging identified the smoothest morphology at $1 \%$ loading. This is further evidence that the presence of the octahedral Ir complex can assist in minimizing phase separation, cavity formation and other morphological defects if implemented correctly.

\section{Figure 7}

In a 2016 report a variety of Ir phosphors $\mathbf{2 4 - 2 7}$ (figure 7) were studied as triplet-singlet energy transfer dopants in a PTB7:PC ${ }_{71} \mathrm{BM}$ BHJ.[124] Photoluminescence spectroscopy confirmed energy transfer between the complexes and PTB7 and the best performing complex $\mathbf{2 5}$ showed little change in $V_{o c}$ and $\mathrm{FF}$ but a significant improvement in $J_{s c}$ from 13.3 to $16.1 \mathrm{~mA} \mathrm{~cm}{ }^{-2}$ increasing $\eta$ from 7.23 to $8.62 \%$. These improvements were correlated to both the efficient energy transfer between dopant and host and the large FRET radius of 25 at $8.2 \mathrm{~nm}$. Similar behavior was identified between 27 and P3HT. This study also identified explicitly that the complex must be blended into the active layer itself to have any effect, simply using the complex as a further layer in its own right did not enhance performance.

A report from earlier this year also used an $\operatorname{Ir}(\mathrm{III})$ phosphor as a FRET pairing with $\mathrm{P} 3 \mathrm{HT}$ and and efficiencies of up to $4.44 \%$ were obtained with $1 \mathrm{wt} \%$ dopant and solvent annealing. This is an improvement of almost 50\% over a non-doped, non-annealed device.[125] Unfortunately however, the complex is written as bis(1-phenylisoquinoline) acetylacetonate iridium(III) Ir(piq)2(acac) 28 but the structure in the supporting information is that of $\mathbf{2 9}$ (both shown in figure 6) therefore these results must be interpreted with some caution.

\section{Iridium Complexes as BHJ Donors}

Despite the promising results obtained using Ir complexes as dopants, a number of studies have employed Ir complexes as donor materials in their own right although the results of these studies have been less encouraging.

\section{Figure 8}

Lee et al. synthesized the short series of complexes 30-32 (figure 8) with 2-picolinic acid as the ancillary ligand which were then employed as donors alongside $\mathrm{PC}_{61} \mathrm{BM}$ in solution processed $\mathrm{BHJs}$ and $\mathrm{C}_{60}$ in thermally evaporated BHJ devices. [126] Photoinduced charge transfer between donor 
and acceptor was identified although photovoltaic performance was low with the best device $0.60 \%$.

In 2012, Wang et al. utilized bis(1,2-diphenyl-1H-benzoimidazole) iridium (acetylacetonate) 33 (fig. 8) in conjunction with $\mathrm{C}_{60}$ to produce vacuum deposited $\mathrm{BL}$ devices.[127] The J-V curves of these devices displayed an S-shaped kink attributes to the low hole mobility of $33\left(\mu=6.49 \times 10^{-6} \mathrm{~cm}^{2} \mathrm{~V}^{-1} \mathrm{~s}^{-}\right.$ $\left.{ }^{1}\right)$. This kink could be resolved by carefully controlling the donor layer thickness and by using a thin layer of a hole transporting material such as NPD (fig. 4) at the donor/anode interface, ultimately producing cells with $V_{o c}=0.78 \mathrm{~V}, J_{s c}=4.82 \mathrm{~mA} \mathrm{~cm}^{-2}, \mathrm{FF}=0.60$ and $\eta=2.23 \%$. An improvement in efficiency of $35 \%$ compared to devices without the NPD layer.

Fleetham and co-workers produced a BL device using the azaperylene complex $\mathbf{3 4}$ (fig. 8) as donor and $C_{60}$ as acceptor.[128] The azaperylene ligand conferred a very broad absorption profile to the complex, with triplet absorption stretching into the near-IR and giving the complex favorable solar energy harvesting properties. The performance of this complex in solar cells was compared to control devices fabricated with platinum(II) octaethylporphine (PtOEP, fig. 8) and zinc(II) phthalocyanine $(\mathrm{ZnPc}) . L_{D}$ for each complex was measured and, as expected, both of the $5 \mathrm{~d}$ metal complexes $34(10.1 \mathrm{~nm})$ and PtOEP $(12.0 \mathrm{~nm})$ had a longer exciton diffusion length than $\mathrm{ZnPc}(<5$ $\mathrm{nm})$. Despite having a slightly shorter $L_{D}$ than PtOEP, $\mathbf{3 4}$ actually produced the most efficient devices at $\eta=2.8 \%$ (rather high for a simple bilayer device) thanks to its improved $V_{o c}$ of $0.99 \mathrm{~V}$ versus $0.62 \mathrm{~V}$ for PtOEP $(\eta=1.8 \%)$, the ZnPc device performed the most poorly $(\eta=1.4 \%)$. The $V_{o c}$ of 34 proved very sensitive to film thickness, but demonstrated robust stability towards temperature over the range of 100-300 K. The differences in $L_{D}$ between 34 and PtOEP and the variations in $V_{o c}$ with respect to film thickness and temperature were attributed by the authors to the influence of the octahedral geometry of $\mathbf{3 4}$ compared to the planar PtOEP molecules of which will tend to stack leading to favorable charge transport pathways.

\section{Figure 9}

At time of writing, the most recent report of a device relying upon an Ir complex as the sole donor in an OSC utilized complexes of 2-(2'-pyridyl)benzothiophene ligands functionalized with 4methoxyphenyl 35 and 4-triphenylamine 36 moieties (figure 9) alongside the acac analogue 2,2,6,6tetramethyl-3,5-heptanedione as the ancillary ligand.[129] These complexes were employed in BHJ devices with $\mathrm{PC}_{71} \mathrm{BM}$ at very high acceptor loadings. Devices were poor with the best performing devices consisting of 35: $\mathrm{PC}_{71} \mathrm{BM}(1: 2.5)$ with $V_{o c}=0.77 \mathrm{~V}, \mathrm{~J}_{s c}=4.30 \mathrm{~mA} \mathrm{~cm}^{-2}, \mathrm{FF}=0.35, \eta=1.2 \%$ and 36: $\mathrm{PC}_{71} \mathrm{BM}(1: 2)$ having $V_{o c}=0.74 \mathrm{~V}, \mathrm{~J}_{s c}=6.52 \mathrm{~mA} \mathrm{~cm}^{-2}, \mathrm{FF}=0.42, \eta=2.0 \%$. The triphenylamine 
substituted $\mathbf{3 6}$ showed better performance in all respects. The authors identified the very short excited state lifetimes of $\mathbf{3 5}$ (108 ns) and $\mathbf{3 6}$ (122 ns) in the solid state as a limiting factor.

\subsection{Group 10}

\section{Palladium and Platinum}

PtOEP (fig. 8) was used in a bilayer device reported by Shao and Yang with $C_{60}$ as acceptor.[130] Despite the low mobility of PtOEP at $\mu=10^{-5} \mathrm{~cm}^{2} \mathrm{~V}^{-1} \mathrm{~s}^{-1}$ a $V_{o c}=0.66 \mathrm{~V}, \mathrm{~J}_{s c}=5.6 \mathrm{~mA} \mathrm{~cm}{ }^{-2}, \mathrm{FF}=0.57$ and $\eta=2.1 \%$ were obtained. $L_{D}$ of the heterojunction was estimated to be $30 \mathrm{~nm}$ by measuring the dependence of $\eta$ on the thickness of the PtOEP layer. The magnitude of $L_{D}$ is ascribed solely to a long exciton lifetime of PtOEP itself which the authors note has a triplet lifetime of approximately 90 $\mu \mathrm{s} .[131]$

Subsequently, Rand et al. doped PtOEP into the poly(p-phenylene vinylene) derivative Super Yellow at a loading of $5 \mathrm{wt} \%$ in a $\mathrm{BL}$ device alongside $\mathrm{C}_{60}$ to obtain a device with a $10 \%$ improvement in photocurrent compared to the non-doped device.[132] They identified that the presence of the heavy Pt atom was essential to producing improved photovoltaic performance by comparing it to a device that used the metal free ligand octaethylporphine as a dopant which lead to a decrease in all device parameters. $L_{D}$ were estimated at 9 and $4 \mathrm{~nm}$ for the sensitized and non-sensitized devices respectively with the difference attributed to the presence of triplet excitons in the PtOEP device.

\section{Figure 10}

In 2007 a single layer solar cell was prepared using the fullerene functionalized thiophene-2,5di(platinum bis(acetylide)) complex 37 (figure 10).[133] It was envisioned that the Pt centers will undergo photoinduced electron transfer to the pendant fullerenes while also encouraging ISC to form triplet charge separated states as the authors had observed for a related polymer in a $\mathrm{BHJ}$ with $\mathrm{PC}_{61} \mathrm{BM}$.[134] While photophysical evidence supported aspects of this postulation, device performance was ultimately poor with $\eta<0.06 \%$ which the authors attributed to the heavy Pt atom assisting in both ISC upon excitation and rapid reverse ISC from the triplet state back to the short lived singlet state.

The groups of Thompson and Forrest conducted comparative studies of Pt and Pd tetraphenylbenzoporphyrin (PtTPBP and PdTPBP, fig. 10) derivatives in layered heterojunction devices with $\mathrm{C}_{60}$ alongside other donors including $\mathrm{CuPc}$, PtOEP, tetracene, rubrene and others. While the overall efficiencies of the TPBP complexes outperformed most other donors (PdTPBP $\eta=1.8 \%$, PtTPBP $\eta=1.9 \%$ ) they did not display the high $J_{s c}$ observed in other triplet sensitized devices due to their poor absorbance with respect to the solar spectrum. $[135,136]$ This was followed by a report on PtTPBP focused on studying the ISC processes occurring in a phosphor doped organic 
semiconductor, specifically diphenyltetracene 38.[137] By controlling the thickness of a film of 38 doped with 5 wt\% PtTBPB this triplet sensitized layer was used as the donor in a BL with $\mathrm{C}_{60}$. The formation of triplet excitons due to the presence of the Pt phosphor in $\mathbf{3 8}$ was identified as occurring in the picosecond timescale and was observed to increase $J_{s c}$ from $30 \mu \mathrm{Acm}^{-2}$ in a film of pristine 38 to $66 \mu \mathrm{A} \mathrm{cm}^{-2}$ in the doped film. In 2009, Li et al. utilized the carbazole functionalized Pt porphine complex 39 (fig. 10) as a dopant in a P3HT: $\mathrm{C}_{60} \mathrm{BL}$ device. Though the extent of doping is not clear the presence of $\mathbf{3 9}$ improved all device properties. $V_{o c}$ and $J_{s c}$ almost doubled going from 0.214 to $0.412 \mathrm{~V}$ and 2.546 to $4.152 \mathrm{~mA} \mathrm{~cm}^{-2}$ which increased $\eta$ from 0.17 to $0.70 \%$. Devices doped with 39 were compared to those doped with CdTe nanoparticles and the molecular dopant was shown to be superior. In a device consisting of just 39: $\mathrm{C}_{60}$ values of $J_{s c}$ and $\eta$ are both very low due to the poor charge carrier mobility of the $\mathrm{Pt}$ complex.[138]

The limitations on $L_{D}$ that are imposed by poor charge mobility were clearly identified in two papers by Jabbour et al.[139,140] which were published concomitantly with a similar investigation by Lane et al.[141] These studies focus on group 10 phthalocyanine complexes and serve well to validate each other. Jabbour's initial study utilized ZnPc, PdPc and PtPc alongside CuPc for comparison.[139] The complexes were incorporated into $\mathrm{BL}$ devices with the acceptor perylene tetracarboxylic bisbenzimidazole (PTCBI). Both the donor and acceptor layers were $20 \mathrm{~nm}$ in thickness and the films of all materials displayed similar morphology. Of the four complexes tested PdPc was the most efficient. While CuPc, $\mathrm{ZnPc}$ and PtPc all displayed $I_{s c} \approx 3.0 \mathrm{~mA} \mathrm{~cm}^{-2}, \mathrm{PdPc}$ had $J_{s c}=4.0 \mathrm{~mA} \mathrm{~cm}^{-2}$ thereby providing the most efficient solar cells. Surprisingly PtPc produced the poorest device due to a very combination of low $J_{s c}$ and the influence of its high HOMO energy limiting the $V_{o c}$. The low $J_{s c}$ of PtPc is perhaps the most surprising result, however estimated $L_{D}$ values increased in the order $\operatorname{PtPc}(5.6 \mathrm{~nm})<\operatorname{CuPc}(5.8 \mathrm{~nm})<\operatorname{ZnPc}(6.2 \mathrm{~nm})<\operatorname{PdPc}(10.1 \mathrm{~nm})$. PtPc was then shown to have a hole mobility almost two orders of magnitude lower than the other members of the series which explains its low $J_{s c}$. The $3 \mathrm{~d}$ metal complexes CuPc and $\mathrm{ZnPc}$ actually displayed the largest charge mobility but only intermediate $J_{s c}$ therefore a combination of high mobility (compared to $\mathrm{Pt}$ ) and enhanced exciton lifetime thanks to ISC explains the improved performance of PdPc. The authors confirmed this by making further devices of CuPc and PdPc with $\mathrm{C}_{60}$ as acceptor and increased $J_{s c}$ was again observed for PdPc. A subsequent comparison of $\mathrm{ZnPc}$ and PdPc in $\mathrm{HJ}$ architectures with a $\mathrm{p}-\mathrm{i}-\mathrm{n}$ configuration yielded similar results.[140] The study by Lane et al. was being conducted at the same time and compared NiPc, PdPc, and PtPc as donors in vacuum deposited BL devices alongside $\mathrm{C}_{60}$. While PtPc outperformed NiPc in this instance due to the higher HOMO of NiPc limiting its $V_{o c}$ 
trends comparable to those observed in the preceding studies were made with PdPc clearly superior to NiPc and PtPc.[141]

\section{Figure 11}

The group of Fréchet synthesized multichromophoric Pt-acetylide oligomers $\mathbf{4 0 - 4 2 ~ ( f i g u r e ~ 1 1 ) ~ w i t h ~}$ varying chain lengths and employed them in $\mathrm{BHJ}$ devices with $\mathrm{PC}_{61} \mathrm{BM}$ and $\mathrm{PC}_{71} \mathrm{BM}$.[142] As the frontier orbitals are located over the Pt acetylide and 2,1,3-benzothiadiazole moieties the optical and electrochemical properties of all three molecules are almost identical, therefore increasing the oligothiophene chain length should only affect charge transport and morphological properties. Ultimately the two shorter oligomers $\mathbf{4 0}$ and $\mathbf{4 1}$ displayed higher charge mobility possibly due to their better film forming properties while the best devices were obtained with the intermediate length terthiophene terminated 41 displaying $V_{o c}=0.82 \mathrm{~V}, J_{s c}=8.45 \mathrm{~mA} \mathrm{~cm}^{-2}, \mathrm{FF}=0.43$ and $\eta=3.0 \%$ in conjunction with $\mathrm{PC}_{71} \mathrm{BM}$.

In a study of platinum acetylide polymers in BHJ solar cells Li et al. synthesized the 9,10anthraquinone oligomers $\mathbf{4 3}$ and $\mathbf{4 4}$ (fig. 11) however they only produced devices with the related polymers in conjunction with $\mathrm{PC}_{61} \mathrm{BM}$ which performed poorly.[143]

$\mathrm{Pd}$ and Pt 8-hydroxyquinoline ( $\mathrm{Pdq}_{2}$ and $\mathrm{Ptq}_{2}$, fig. 11) and 5,7-dimethyl-8-hydroxyquinoline complexes ( $\mathrm{PdMe}_{2} \mathrm{q}_{2}$ and $\mathrm{PtMe}_{2} \mathrm{q}_{2}$, fig. 11) were reported by Che et al. in 2011 and were incorporated by vacuum deposition into organic field effect transistor (OFET) and BL solar cell devices with $\mathrm{C}_{60}$ as acceptor. While the $\mathrm{Pd}$ and $\mathrm{Pt}$ complexes displayed similar morphologies the $\mathrm{Pt}$ complexes in this instance had marginally higher charge mobility than their Pd analogues as measured in the OFETs and also produced more efficient solar cells. The $J_{s c}$ of $\mathrm{Pt}\left(\mathrm{Me}_{2} \mathrm{q}\right)_{2}$ based OSCs was particularly high at $14.8 \mathrm{~mA} \mathrm{~cm}^{-2}$ and it had a $V_{o c}=0.42 \mathrm{~V}, \mathrm{FF}=0.38$ and $\eta=2.4 \%$.[144]

Figure 12

A further series of Pt acetylide oligomers 45-48 (figure 12) published in 2012 were studied in OFET and $\mathrm{BHJ}$ devices at a range of film thicknesses.[145] $\mathrm{PC}_{71} \mathrm{BM}$ was used as the acceptor in a ratio of 45-48: $\mathrm{PC}_{71} \mathrm{BM}=1: 4.45$ and 46 ultimately produced devices with high $J_{s c}>7.0 \mathrm{~mA} \mathrm{~cm}^{-2}$ and $\eta=2.37$ and $2.34 \%$ respectively. Again, the BHJ performance correlated well with the OFET measured mobility.

In 2015 multichromophoric Pt bis(acetylide) complexes 49 and $\mathbf{5 0}$ (fig. 12) were produced with the best performing $\mathrm{BHJ}$ device consisting of $49: \mathrm{PC}_{71} \mathrm{BM}(1: 1)$ displaying $V_{o c}=0.75 \mathrm{~V}, \mathrm{~J}_{s c}=4.14 \mathrm{~mA} \mathrm{~cm}{ }^{-2}$, $\mathrm{FF}=0.45$ and $\eta=1.40 \%$ in the presence of the additive 1,8-diiodooctane.[146]

Figure 13 
Ma et al. used a triphenylamine substituted porphyrin to produce a range of metal complexes studies on Pc complexes[139-141] Pt was outperformed again by the Pd complex 52. The triplet

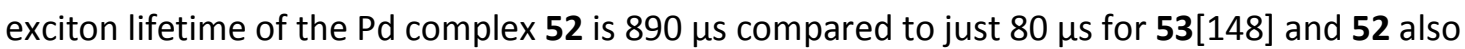
proved to have the best charge transport properties with a hole mobility of $1.4 \times 10^{-4} \mathrm{~cm}^{2} \mathrm{~V}^{-1} \mathrm{~s}^{-1}$ compared to $6.2 \times 10^{-5} \mathrm{~cm}^{2} \mathrm{~V}^{-1} \mathrm{~s}^{-1}$. The OSC of $\mathbf{5 2}$ displayed the highest performance by a significant margin having $V_{o c}=0.90 \mathrm{~V}, J_{s c}=2.70 \mathrm{~mA} \mathrm{~cm}^{-2}, \mathrm{FF}=0.25$ and $\eta=0.84 \%$.

Finally, in 2016 Qin and collaborators presented cruciform Pt-bis(acetylide) complexes 54 and 55 (fig. 13) which they employed in $\mathrm{BHJ}$ devices with $\mathrm{PC}_{61} \mathrm{BM}$ and $P \mathrm{C}_{71} \mathrm{BM}$.[149] The devices of 54 displayed high FF compared to other Pt bis(acetylide) complexes and in optimized BHJ displayed $J_{s c}$ values as high as $11.9 \mathrm{~mA} \mathrm{~cm}^{-2}$ for $54: \mathrm{PC}_{71} \mathrm{BM}(1: 0.8)$ and $10.7 \mathrm{~mA} \mathrm{~cm}^{-2}$ for $54: \mathrm{PC}_{61} \mathrm{BM}(1: 0.8)$ leading to $\eta=5.6$ and $5.1 \%$ respectively. These are very high values compared to other devices consisting of a sole Pt donor.

\subsection{Group 11}

\section{Gold}

\section{Figure 14}

In 2014 Lai et al. reported the synthesis of three $A u(I I I)$ corrole complexes 56-58 (figure 14)and used them as donor materials in vacuum deposited OSCs with $\mathrm{C}_{70}$ and as triplet sensitizers for the polymer PTB7 in solution processed BHJ devices with $\mathrm{PC}_{71} \mathrm{BM}$.[150] Monolayer devices of $\mathrm{C}_{70}$ alone displayed $V_{o c}=1.23 \mathrm{~V}, J_{s c}=1.19 \mathrm{~mA} \mathrm{~cm}{ }^{-2}, \mathrm{FF}=0.32$ and $\eta=0.5 \%$. Upon addition of just $5 \%$ of the standout material 57 to the $C_{70}$ the post-annealing $J_{s c}$ increased almost tenfold to $10.34 \mathrm{~mA} \mathrm{~cm}^{-2}$ and the FF improved to 0.46 , these improvements offset a drop in $V_{o c}$ from 1.23 to $0.85 \mathrm{~V}$ and resulted in a device with $\eta=4.0 \%$ overall. All of the complexes $56-58$ led to improved performance at loading of only $3-7 \%$ therefore it is not unreasonable to consider them as having "doped" $\mathrm{C}_{70}$ as much as having acted as a formal donor. A similar improvement in the performance of a solution processed PTB7:PC ${ }_{71} \mathrm{BM}$ BHJ was observed upon addition of $5 \% 57$ which led to a $V_{o c}=0.74 \mathrm{~V}, J_{s c}=14.18 \mathrm{~mA}$ $\mathrm{cm}^{-2}, \mathrm{FF}=0.57$ and $\eta=6.0 \%$. Compared to the fullerene-only devices the presence of the donor polymer PTB7 had a very beneficial effect on the FF.

\subsection{Others}

Mixed porphyrin/phthalocyanine sandwich complexes of a number of lanthanides have employed in devices which seem like a hybrid of a $\mathrm{BHJ}$ and a DSSC using $\mathrm{PC}_{61} \mathrm{BM}$ or $N, N^{\prime}$-bis(1-ethylhexyl)3,4,9,10-perylenebis(dicarboximide) (PDI) as acceptor and a "buffer layer" of $\mathrm{TiO}_{2}$. Device 
performance is modest with the best $\eta=0.82 \%$ for Eu(III) but many of the devices did not function at all without $\mathrm{TiO}_{2}$ being present. $[151,152]$

\section{Summary and Outlook}

The studies presented here clearly show that the presence of a metal based triplet sensitizer can provide notable improvements in one or all of the key performance indicators in OSCs with $J_{s c}$ values showing particularly pronounced improvements due to energy transfer processes leading to increased triplet population and extended $L_{D}$.

Comparing the results obtained using metal complexes as dopants to those using the same or similar complexes as the sole donor material, it is quite clear that the former approach presents the greatest promise. The majority of these complexes have low charge mobility themselves and the sheer cost of precious metal complexes would appear to preclude their use as a major component of any device. Metal complex dopants also show a strong influence on heterojunction morphology which presents another opportunity to use these materials to influence charge transport properties. The results obtained using $\mathrm{Au}(\mathrm{III})$ corroles as donors are particularly compelling as some of these devices are essentially sensitized fullerene monolayers and the presence of a small amount of these complexes resulted in a tenfold increase in the short circuit current of the fullerene. The tendency for planar Pd complexes to outperform those of Pt complexes is also noteworthy as studies of Pd complexes as active components in organic optoelectronics are much less frequently encountered. Though challenges remain including truly unravelling the underlying mechanisms of operation, identifying structure-property relationships that influence charge carrier transport, and controlling the location and distribution of the metal phosphors in the ternary blend,[153] the fact that addition of very small amounts of metal complexes to the active layer has already been observed to improve $\mathrm{BHJ}$ efficiencies by up to four times identifies that this is a truly promising approach to the continued development of $\mathrm{BHJ}$ technologies. The knowledge being gained from studies on other ternary systems should be extremely helpful in advancing this premise.

Producing molecules with bespoke optical and electronic behavior is an ideal area for inorganic and particularly coordination chemists to thrive therefore the application of metal complexes to $\mathrm{BHJ}$ solar cells can provide fertile ground for the development of useful new materials and technologies.

\section{Acknowledgements}

IAW would like to thank Loughborough University for financial support.

\section{References}


[1] B. O'Regan, M. Grätzel, A low-cost, high-efficiency solar cell based on dye-sensitized colloidal TiO2 films, Nature. 353 (1991) 737-740. doi:10.1038/353737a0.

[2] M.K. Nazeeruddin, A. Kay, I. Rodicio, R. Humphry-Baker, E. Müller, P. Liska, N. Vlachopoulos, M. Grätzel, Conversion of Light to Electricity by cis-X2Bis (2,2'-bipyridyl-4,4'-dicarboxylate) ruthenium (II) Charge-Transfer Sensitizers ( $\mathrm{X}=\mathrm{Cl}-, \mathrm{Br}-, \mathrm{I}-, \mathrm{CN}-$, and $\mathrm{SCN}-$ ) on Nanocrystalline TiO2 Electrodes, J. Am. Chem. Soc. 115 (1993) 6382-6390. doi:10.1021/ja00067a063.

[3] M.K. Nazeeruddin, S.M. Zakeeruddin, R. Humphry-Baker, M. Jirousek, P. Liska, N. Vlachopoulos, V. Shklover, C.-H. Fischer, M. Grätzel, Acid-Base Equilibria of (2,2'-Bipyridyl4,4'-dicarboxylic acid)ruthenium(II) Complexes and the Effect of Protonation on ChargeTransfer Sensitization of Nanocrystalline Titania, Inorg. Chem. 38 (1999) 6298-6305. doi:10.1021/ic990916a.

[4] M. Grätzel, Dye-sensitized solar cells, J. Photochem. Photobiol. C Photochem. Rev. 4 (2003) 145-153. doi:10.1016/S1389-5567(03)00026-1.

[5] A.S. Polo, M.K. Itokazu, N.Y. Murakami Iha, Metal complex sensitizers in dye-sensitized solar cells, Coord. Chem. Rev. 248 (2004) 1343-1361. doi:10.1016/j.ccr.2004.04.013.

[6] M. Grätzel, Solar energy conversion by dye-sensitized photovoltaic cells, Inorg. Chem. 44 (2005) 6841-6851. doi:10.1021/ic0508371.

[7] N. Robertson, Optimizing dyes for dye-sensitized solar cells, Angew. Chemie - Int. Ed. 45 (2006) 2338-2345. doi:10.1002/anie.200503083.

[8] A. Hagfeldt, G. Boschloo, L. Sun, L. Kloo, H. Pettersson, Dye-sensitized solar cells, Chem. Rev. 110 (2010) 6595-6663. doi:10.1021/cr900356p.

[9] Y. Sun, A.C. Onicha, M. Myahkostupov, F.N. Castellano, Viable Alternative to N719 for DyeSensitized Solar Cells, ACS Appl. Mater. Interfaces. 2 (2010) 2039-2045. doi:10.1021/am100311m.

[10] B. Pashaei, H. Shahroosvand, M. Graetzel, M.K. Nazeeruddin, Influence of Ancillary Ligands in Dye-Sensitized Solar Cells, Chem. Rev. 116 (2016) 9485-9564. doi:10.1021/acs.chemrev.5b00621.

[11] M. Grätzel, Recent advances in sensitized mesoscopic solar cells, Acc. Chem. Res. 42 (2009) 1788-1798. doi:10.1021/ar900141y. 
[12] H. Nusbaumer, J.E. Moser, S.M. Zakeeruddin, M.K. Nazeeruddin, M. Gr??tzel, Coll(dbbip)22+ complex rivals tri-iodide/iodide redox mediator in dye-sensitized photovoltaic cells, J. Phys. Chem. B. 105 (2001) 10461-10464. doi:10.1021/jp012075a.

[13] S.M. Feldt, E.A. Gibson, E. Gabrielsson, L. Sun, G. Boschloo, A. Hagfeldt, Design of organic dyes and cobalt polypyridine redox mediators for high-efficiency dye-sensitized solar cells, J. Am. Chem. Soc. 132 (2010) 16714-16724. doi:10.1021/ja1088869.

[14] D. Zhou, Q. Yu, N. Cai, Y. Bai, Y. Wang, P. Wang, Efficient organic dye-sensitized thin-film solar cells based on the tris(1,10-phenanthroline)cobalt(II/III) redox shuttle, Energy Environ. Sci. 4 (2011) 2030. doi:10.1039/c0ee00735h.

[15] A. Yella, H.-W. Lee, H.N. Tsao, C. Yi, A.K. Chandiran, M.K. Nazeeruddin, E.W.-G. Diau, C.-Y. Yeh, S.M. Zakeeruddin, M. Gratzel, Porphyrin-Sensitized Solar Cells with Cobalt (II/III)-Based Redox Electrolyte Exceed 12 Percent Efficiency, Science (80-. ). 334 (2011) 629-634. doi:10.1126/science.1209688.

[16] J.-H. Yum, E. Baranoff, F. Kessler, T. Moehl, S. Ahmad, T. Bessho, A. Marchioro, E. Ghadiri, J.-E. Moser, C. Yi, M.K. Nazeeruddin, M. Grätzel, A cobalt complex redox shuttle for dye-sensitized solar cells with high open-circuit potentials, Nat. Commun. 3 (2012) 631. doi:10.1038/ncomms1655.

[17] T.W. Hamann, The end of iodide? Cobalt complex redox shuttles in DSSCs, Dalt. Trans. 41 (2012) 3111. doi:10.1039/c2dt12362b.

[18] K. Ben Aribia, T. Moehl, S.M. Zakeeruddin, M. Grätzel, Tridentate cobalt complexes as alternative redox couples for high-efficiency dye-sensitized solar cells, Chem. Sci. 4 (2013) 454-459. doi:10.1039/C2SC21401F.

[19] B. Bozic-Weber, E.C. Constable, S.O. Fürer, C.E. Housecroft, L.J. Troxler, J.A. Zampese, Copper(i) dye-sensitized solar cells with [Co(bpy)3]2+/3+ electrolyte, Chem. Commun. 49 (2013) 7222. doi:10.1039/c3cc44595j.

[20] S.O. Fürer, B. Bozic-Weber, T. Schefer, C. Wobill, E.C. Constable, C.E. Housecroft, M. Willgert, Understanding why replacing $\mathrm{I}_{3}{ }^{-} / \mathrm{I}^{-}$by cobalt $(\langle\operatorname{scp}>\mathrm{ii}</ \operatorname{scp}\rangle) /(\langle\mathrm{scp}>\mathrm{iii}</ \operatorname{scp}\rangle)$ electrolytes in bis(diimine)copper( $\langle\operatorname{scp}>\mathrm{i}</ \mathrm{scp}>$ )-based dye-sensitized solar cells improves performance, J. Mater. Chem. A. 4 (2016) 12995-13004. doi:10.1039/C6TA04879J.

[21] F. Bella, S. Galliano, C. Gerbaldi, G. Viscardi, Cobalt-based electrolytes for dye-sensitized solar 
cells: Recent advances towards stable devices, Energies. 9 (2016) 1-22. doi:10.3390/en9050384.

[22] K.Y. Chen, C. Du, B.O. Patrick, C.P. Berlinguette, High-Voltage Dye-Sensitized Solar Cells Mediated by [Co(2,2'-bipyrimidine) $\left.{ }_{3}\right]^{2}$, Inorg. Chem. 56 (2017) 2383-2386. doi:10.1021/acs.inorgchem.7b00082.

[23] T. Bessho, E.C. Constable, M. Graetzel, A. Hernandez Redondo, C.E. Housecroft, W. Kylberg, M.K. Nazeeruddin, M. Neuburger, S. Schaffner, An element of surprise-efficient copperfunctionalized dye-sensitized solar cells, Chem. Commun. (2008) 3717. doi:10.1039/b808491b.

[24] E.C. Constable, A.H. Redondo, C.E. Housecroft, M. Neuburger, S. Schaffner, Copper(i) complexes of 6,6'-disubstituted 2,2'-bipyridine dicarboxylic acids: new complexes for incorporation into copper-based dye sensitized solar cells (DSCs), Dalt. Trans. (2009) 6634. doi:10.1039/b901346f.

[25] N. Robertson, Cu 'versus Ru " : Dye-Sensitized Solar Cells and Beyond, ChemSusChem. 1 (2008) 977-979. doi:10.1002/cssc.200800214.

[26] M. Sandroni, Y. Pellegrin, F. Odobel, Heteroleptic bis-diimine copper(I) complexes for applications in solar energy conversion, Comptes Rendus Chim. 19 (2016) 79-93. doi:10.1016/j.crci.2015.06.008.

[27] B. Bozic-Weber, S.Y. Brauchli, E.C. Constable, S.O. Fürer, C.E. Housecroft, I.A. Wright, Holetransport functionalized copper(i) dye sensitized solar cells, Phys. Chem. Chem. Phys. 15 (2013) 4500. doi:10.1039/c3cp50562f.

[28] B. Bozic-Weber, S.Y. Brauchli, E.C. Constable, S.O. Fürer, C.E. Housecroft, F.J. Malzner, I.A. Wright, J.A. Zampese, Improving the photoresponse of copper(i) dyes in dye-sensitized solar cells by tuning ancillary and anchoring ligand modules, Dalt. Trans. 42 (2013) 12293. doi:10.1039/c3dt51416a.

[29] N. Alonso-Vante, J.-F. Nierengarten, J.-P. Sauvage, Spectral sensitization of large-band-gap semiconductors (thin films and ceramics) by a carboxylated bis(1,10-phenanthroline)copper(I) complex, J. Chem. Soc. Dalt. Trans. 11 (1994) 1649. doi:10.1039/dt9940001649.

[30] S. Sakaki, T. Kuroki, T. Hamada, Synthesis of a new copper(i) complex, [Cu(tmdcbpy)2]+ (tmdcbpy $=4,4^{\prime}, 6,6^{\prime}$-tetramethyl-2,2'-bipyridine-5,5'-dicarboxylic acid), and its application to 
solar cells, J. Chem. Soc. Dalt. Trans. (2002) 840. doi:10.1039/b109518h.

[31] C.E. Housecroft, E.C. Constable, The emergence of copper( $\langle\operatorname{scp}\rangle i\langle/ \operatorname{scp}\rangle$ )-based dye sensitized solar cells, Chem. Soc. Rev. 44 (2015) 8386-8398. doi:10.1039/C5CS00215J.

[32] M. Magni, P. Biagini, A. Colombo, C. Dragonetti, D. Roberto, A. Valore, Versatile copper complexes as a convenient springboard for both dyes and redox mediators in dye sensitized solar cells, Coord. Chem. Rev. 322 (2016) 69-93. doi:10.1016/j.ccr.2016.05.008.

[33] B. Bozic-Weber, E.C. Constable, N. Hostettler, C.E. Housecroft, R. Schmitt, E. Schönhofer, The d10 route to dye-sensitized solar cells: step-wise assembly of zinc(ii) photosensitizers on $\mathrm{TiO}_{2}$ surfaces, Chem. Commun. 48 (2012) 5727. doi:10.1039/c2cc31729j.

[34] N. Hostettler, I.A. Wright, B. Bozic-Weber, E.C. Constable, C.E. Housecroft, Dye-sensitized solar cells with hole-stabilizing surfaces: "inorganic" versus "organic" strategies, RSC Adv. 5 (2015) 37906-37915. doi:10.1039/C5RA05630F.

[35] B. Bozic-Weber, E.C. Constable, C.E. Housecroft, Light harvesting with Earth abundant d-block metals: Development of sensitizers in dye-sensitized solar cells (DSCs), Coord. Chem. Rev. 257 (2013) 3089-3106. doi:10.1016/j.ccr.2013.05.019.

[36] B. Pashaei, H. Shahroosvand, P. Abbasi, Transition metal complex redox shuttles for dyesensitized solar cells, RSC Adv. 5 (2015) 94814-94848. doi:10.1039/C5RA13088C.

[37] A. Kojima, K. Teshima, Y. Shirai, T. Miyasaka, Organometal halide perovskites as visible-light sensitizers for photovoltaic cells, J. Am. Chem. Soc. 131 (2009) 6050-6051. doi:10.1021/ja809598r.

[38] M.A. Green, A. Ho-Baillie, H.J. Snaith, The emergence of perovskite solar cells, Nat. Photonics. 8 (2014) 506-514. doi:10.1038/nphoton.2014.134.

[39] S.D. Stranks, H.J. Snaith, Metal-halide perovskites for photovoltaic and light-emitting devices, Nat. Nanotechnol. 10 (2015) 391-402. doi:10.1038/nnano.2015.90.

[40] S. Yang, W. Fu, Z. Zhang, H. Chen, C.-Z. Li, Recent advances in perovskite solar cells: efficiency, stability and lead-free perovskite, J. Mater. Chem. A. 5 (2017) 11462-11482. doi:10.1039/C7TA00366H.

[41] M. Konstantakou, T. Stergiopoulos, A critical review on tin halide perovskite solar cells, J. Mater. Chem. A. 5 (2017) 11518-11549. doi:10.1039/C7TA00929A. 
[42] A.B. Djurišić, F.Z. Liu, H.W. Tam, M.K. Wong, A. Ng, C. Surya, W. Chen, Z.B. He, Perovskite solar cells - An overview of critical issues, Prog. Quantum Electron. 53 (2017) 1-37. doi:10.1016/j.pquantelec.2017.05.002.

[43] J. Roncali, Molecular bulk heterojunctions: An emerging approach to organic solar cells, Acc. Chem. Res. 42 (2009) 1719-1730. doi:10.1021/ar900041b.

[44] B. Walker, C. Kim, T.Q. Nguyen, Small molecule solution-processed bulk heterojunction solar cells, Chem. Mater. 23 (2011) 470-482. doi:10.1021/cm102189g.

[45] Y. Lin, Y. Li, X. Zhan, Small molecule semiconductors for high-efficiency organic photovoltaics, Chem. Soc. Rev. 41 (2012) 4245. doi:10.1039/c2cs15313k.

[46] A. Mishra, P. Bäuerle, Small molecule organic semiconductors on the move: Promises for future solar energy technology, Angew. Chemie - Int. Ed. 51 (2012) 2020-2067. doi:10.1002/anie.201102326.

[47] Q. Huang, H. Li, Recent progress of bulk heterojunction solar cells based on small-molecular donors, Chinese Sci. Bull. 58 (2013) 2677-2685. doi:10.1007/s11434-013-5930-z.

[48] G. V Bulavko, A.A. Ishchenko, Organic bulk heterojunction photovoltaic structures: design, morphology and properties, Russ. Chem. Rev. 83 (2014) 575-599. doi:10.1070/RC2014v083n07ABEH004417.

[49] Y. Lin, X. Zhan, Oligomer Molecules for Efficient Organic Photovoltaics, Acc. Chem. Res. 49 (2016) 175-183. doi:10.1021/acs.accounts.5b00363.

[50] O. Ostroverkhova, Organic Optoelectronic Materials: Mechanisms and Applications, Chem. Rev. 116 (2016) 13279-13412. doi:10.1021/acs.chemrev.6b00127.

[51] A. Arjona-Esteban, M.R. Lenze, K. Meerholz, F. Würthner, Donor-acceptor dyes for organic photovoltaics, in: Adv. Polym. Sci., 2017: pp. 193-214. doi:10.1007/978-3-319-28338-8_8.

[52] S.D. Collins, N.A. Ran, M.C. Heiber, T.Q. Nguyen, Small is Powerful: Recent Progress in Solution-Processed Small Molecule Solar Cells, Adv. Energy Mater. 7 (2017) 1602242. doi:10.1002/aenm.201602242.

[53] G. Yu, J. Gao, J.C. Hummelen, F. Wudl, A.J. Heeger, Polymer Photovoltaic Cells: Enhanced Efficiencies via a Network of Internal Donor-Acceptor Heterojunctions, Science (80-. ). 270 (1995) 1789-1791. doi:10.1126/science.270.5243.1789. 
[54] C. Winder, N.S. Sariciftci, Low bandgap polymers for photon harvesting in bulk heterojunction solar cells, J. Mater. Chem. 14 (2004) 1077. doi:10.1039/b306630d.

[55] E. Bundgaard, F.C. Krebs, Low band gap polymers for organic photovoltaics, Sol. Energy Mater. Sol. Cells. 91 (2007) 954-985. doi:10.1016/j.solmat.2007.01.015.

[56] G. Dennler, M.C. Scharber, C.J. Brabec, Polymer-fullerene bulk-heterojunction solar cells, Adv. Mater. 21 (2009) 1323-1338. doi:10.1002/adma.200801283.

[57] A. Facchetti, $\pi$-Conjugated polymers for organic electronics and photovoltaic cell applications, Chem. Mater. 23 (2011) 733-758. doi:10.1021/cm102419z.

[58] Y. Li, Molecular design of photovoltaic materials for polymer solar cells: Toward suitable electronic energy levels and broad absorption, Acc. Chem. Res. 45 (2012) 723-733. doi:10.1021/ar2002446.

[59] L. Lu, T. Zheng, Q. Wu, A.M. Schneider, D. Zhao, L. Yu, Recent Advances in Bulk Heterojunction Polymer Solar Cells, Chem. Rev. 115 (2015) 12666-12731. doi:10.1021/acs.chemrev.5b00098.

[60] S. Holliday, Y. Li, C.K. Luscombe, Recent advances in high performance donor-acceptor polymers for organic photovoltaics, Prog. Polym. Sci. 70 (2017) 34-51. doi:10.1016/j.progpolymsci.2017.03.003.

[61] R. Hildner, A. Köhler, P. Müller-Buschbaum, F. Panzer, M. Thelakkat, ח-Conjugated Donor Polymers: Structure Formation and Morphology in Solution, Bulk and Photovoltaic Blends, Adv. Energy Mater. 7 (2017) 1700314. doi:10.1002/aenm.201700314.

[62] N.S. Sariciftci, Role of Buckminsterfullerene, C60, in organic photoelectric devices, Prog. Quantum Electron. 19 (1995) 131-159. doi:10.1016/0079-6727(94)00012-N.

[63] R. Ganesamoorthy, G. Sathiyan, P. Sakthivel, Review: Fullerene based acceptors for efficient bulk heterojunction organic solar cell applications, Sol. Energy Mater. Sol. Cells. 161 (2017) 102-148. doi:10.1016/j.solmat.2016.11.024.

[64] Y. Lin, X. Zhan, Non-fullerene acceptors for organic photovoltaics: an emerging horizon, Mater. Horizons. 1 (2014) 470. doi:10.1039/C4MH00042K.

[65] A.F. Eftaiha, J.-P. Sun, I.G. Hill, G.C. Welch, Recent advances of non-fullerene, small molecular acceptors for solution processed bulk heterojunction solar cells, J. Mater. Chem. A. 2 (2014) 
1201-1213. doi:10.1039/C3TA14236A.

[66] F. Fernández-Lázaro, N. Zink-Lorre, Á. Sastre-Santos, Perylenediimides as non-fullerene acceptors in bulk-heterojunction solar cells (BHJSCs), J. Mater. Chem. A. 4 (2016) 9336-9346. doi:10.1039/C6TA02045C.

[67] C.W. Tang, Two-layer organic photovoltaic cell, Appl. Phys. Lett. 48 (1986) 183-185. doi:10.1063/1.96937.

[68] H. Hoppe, N.S. Sariciftci, Organic solar cells: An overview, J. Mater. Res. 19 (2004) 1924-1945. doi:10.1557/JMR.2004.0252.

[69] H. Spanggaard, F.C. Krebs, A brief history of the development of organic and polymeric photovoltaics, Sol. Energy Mater. Sol. Cells. 83 (2004) 125-146.

doi:10.1016/j.solmat.2004.02.021.

[70] T. Ameri, P. Khoram, J. Min, C.J. Brabec, Organic ternary solar cells: A review, Adv. Mater. 25 (2013) 4245-4266. doi:10.1002/adma.201300623.

[71] Q. An, F. Zhang, J. Zhang, W. Tang, Z. Deng, B. Hu, Versatile ternary organic solar cells: a critical review, Energy Environ. Sci. 9 (2016) 281-322. doi:10.1039/C5EE02641E.

[72] P. Cheng, X. Zhan, Versatile third components for efficient and stable organic solar cells, Mater. Horiz. 2 (2015) 462-485. doi:10.1039/C5MH00090D.

[73] F. Goubard, G. Wantz, Ternary blends for polymer bulk heterojunction solar cells, Polym. Int. 63 (2014) 1362-1367. doi:10.1002/pi.4636.

[74] T.M. Clarke, J.R. Durrant, Charge photogeneration in organic solar cells, Chem. Rev. 110 (2010) 6736-6767. doi:10.1021/cr900271s.

[75] C. Deibel, V. Dyakonov, C.J. Brabec, Organic Bulk-Heterojunction Solar Cells, IEEE J. Sel. Top. Quantum Electron. 16 (2010) 1517-1527. doi:10.1109/JSTQE.2010.2048892.

[76] A.J. Heeger, 25th anniversary article: Bulk heterojunction solar cells: Understanding the mechanism of operation, Adv. Mater. 26 (2014) 10-28. doi:10.1002/adma.201304373.

[77] A.W. Hains, Z. Liang, M.A. Woodhouse, B.A. Gregg, Molecular semiconductors in organic photovoltaic cells, Chem. Rev. 110 (2010) 6689-6735. doi:10.1021/cr9002984.

[78] G.J. Hedley, A. Ruseckas, I.D.W. Samuel, Light Harvesting for Organic Photovoltaics, Chem. 
Rev. 117 (2017) 796-837. doi:10.1021/acs.chemrev.6b00215.

[79] G. Baryshnikov, B. Minaev, H. Ågren, Theory and Calculation of the Phosphorescence Phenomenon, Chem. Rev. 117 (2017) 6500-6537. doi:10.1021/acs.chemrev.7b00060.

[80] A.R. Bin Mohd Yusoff, A.J. Huckaba, M.K. Nazeeruddin, Phosphorescent Neutral Iridium (III) Complexes for Organic Light-Emitting Diodes, Top. Curr. Chem. 375 (2017) 39. doi:10.1007/s41061-017-0126-7.

[81] A.F. Henwood, E. Zysman-Colman, Luminescent Iridium Complexes Used in Light-Emitting Electrochemical Cells (LEECs), Top. Curr. Chem. 374 (2016) 36. doi:10.1007/s41061-016-00360.

[82] H. Yersin, A.F. Rausch, R. Czerwieniec, T. Hofbeck, T. Fischer, The triplet state of organotransition metal compounds. Triplet harvesting and singlet harvesting for efficient OLEDs, Coord. Chem. Rev. 255 (2011) 2622-2652. doi:10.1016/j.ccr.2011.01.042.

[83] M.B. Smith, J. Michl, Singlet fission, Chem. Rev. 110 (2010) 6891-6936. doi:10.1021/cr1002613.

[84] J. Lee, P. Jadhav, P.D. Reusswig, S.R. Yost, N.J. Thompson, D.N. Congreve, E. Hontz, T. Van Voorhis, M.A. Baldo, Singlet exciton fission photovoltaics, Acc. Chem. Res. 46 (2013) 13001311. doi:10.1021/ar300288e.

[85] S.R. Yost, E. Hontz, S. Yeganeh, T. Van Voorhis, Triplet vs singlet energy transfer in organic semiconductors: The tortoise and the hare, J. Phys. Chem. C. 116 (2012) 17369-17377. doi:10.1021/jp304433t.

[86] J. Lee, P. Jadhav, P.D. Reusswig, S.R. Yost, N.J. Thompson, D.N. Congreve, E. Hontz, T. Van Voorhis, M.A. Baldo, Singlet Exciton Fission Photovoltaics, Acc. Chem. Res. 46 (2013) 13001311. doi:10.1021/ar300288e.

[87] O. V. Mikhnenko, P.W.M. Blom, T.-Q. Nguyen, Exciton diffusion in organic semiconductors, Energy Environ. Sci. 8 (2015) 1867-1888. doi:10.1039/C5EE00925A.

[88] S.E. Braslavsky, E. Fron, H.B. Rodríguez, E.S. Román, G.D. Scholes, G. Schweitzer, B. Valeur, J. Wirz, Pitfalls and limitations in the practical use of Förster's theory of resonance energy transfer, Photochem. Photobiol. Sci. 7 (2008) 1444. doi:10.1039/b810620g.

[89] A. Olaya-Castro, G.D. Scholes, Energy transfer from Förster-Dexter theory to quantum 
coherent light-harvesting, Int. Rev. Phys. Chem. 30 (2011) 49-77. doi:10.1080/0144235X.2010.537060.

[90] J.L. Brédas, J.E. Norton, J. Cornil, V. Coropceanu, Molecular understanding of organic solar cells: The challenges, Acc. Chem. Res. 42 (2009) 1691-1699. doi:10.1021/ar900099h.

[91] O. V. Mikhnenko, R. Ruiter, P.W.M. Blom, M.A. Loi, Direct Measurement of the Triplet Exciton Diffusion Length in Organic Semiconductors, Phys. Rev. Lett. 108 (2012) 137401. doi:10.1103/PhysRevLett.108.137401.

[92] J.H. Vella, A. Parthasarathy, K.S. Schanze, Triplet sensitization in an anionic poly(phenyleneethynylene) conjugated polyelectrolyte by cationic iridium complexes, J. Phys. Chem. A. 117 (2013) 7818-7822. doi:10.1021/jp405577z.

[93] K.C. Wai, C.S. Hui, K.Y.K. Man, W.C. Kai, L.W. Hei, N. Zhu, A.B. Djurišić, Synthesis and photosensitizing properties of conjugated polymers that contain chlorotricarbonyl bis(phenylimino)acenaphthene rhenium(I) complexes, Coord. Chem. Rev. 249 (2005) 13511359. doi:10.1016/j.ccr.2004.10.006.

[94] J. Kesters, P. Verstappen, M. Kelchtermans, L. Lutsen, D. Vanderzande, W. Maes, PorphyrinBased Bulk Heterojunction Organic Photovoltaics: The Rise of the Colors of Life, Adv. Energy Mater. 5 (2015) 1500218. doi:10.1002/aenm.201500218.

[95] Y.N. Liu, S.F. Wang, Y.T. Tao, W. Huang, Heavy metal complex containing organic/polymer materials for bulk-heterojunction photovoltaic devices, Chinese Chem. Lett. 27 (2016) 12501258. doi:10.1016/j.cclet.2016.07.018.

[96] M.S. Khan, M.K. Al-Suti, J. Maharaja, A. Haque, R. Al-Balushi, P.R. Raithby, Conjugated polyynes and poly(metalla-ynes) incorporating thiophene-based spacers for solar cell (SC) applications, J. Organomet. Chem. 812 (2016) 13-33. doi:10.1016/j.jorganchem.2015.10.003.

[97] M. Kumar, A. Kumar, Performance assessment and degradation analysis of solar photovoltaic technologies: A review, Renew. Sustain. Energy Rev. 78 (2017) 554-587. doi:10.1016/j.rser.2017.04.083.

[98] M.C. Scharber, On the Efficiency Limit of Conjugated Polymer:Fullerene-Based Bulk Heterojunction Solar Cells, Adv. Mater. 28 (2016) 1994-2001. doi:10.1002/adma.201504914.

[99] D.J. Stufkens, The Remarkable Properties of a-Diimine Rhenium Tricarbonyl Complexes in Their Metal-to-Ligand Charge-Transfer (MLCT) Excited States, Comments Inorg. Chem. 13 
(1992) 359-385. doi:10.1080/02603599208048467.

[100] K.S. Schanze, D. Brent MacQueen, T.A. Perkins, L.A. Cabana, Studies of intramolecular electron and energy transfer using the fac-(diimine)Rel(CO)3 chromophore, Coord. Chem. Rev. 122 (1993) 63-89. doi:10.1016/0010-8545(93)80042-4.

[101] L.S.M. Lam, W.K. Chan, Photosensitizing Properties of Some Rhenium(I) Tricarbonyl Diimine Complexes, ChemPhysChem. 2 (2001) 252-256. doi:10.1002/14397641(20010417)2:4<252::AID-CPHC252>3.3.CO;2-N.

[102] L.S.M. Lam, W.K. Chan, A.B. Djurišić, E. Herbert Li, Study of charge generation process in some photosensitizing rhenium diimine complexes, Chem. Phys. Lett. 362 (2002) 130-134. doi:10.1016/S0009-2614(02)01045-X.

[103] H.L. Wong, L.S.M. Lam, K.W. Cheng, K.Y.K. Man, W.K. Chan, C.Y. Kwong, A.B. Djurišić, Lowband-gap, sublimable rhenium(I) diimine complex for efficient bulk heterojunction photovoltaic devices, Appl. Phys. Lett. 84 (2004) 2557-2559. doi:10.1063/1.1682676.

[104] H.L. Wong, K.W. Cheng, K.K.Y. Man, C.Y. Kwong, W.K. Chan, A.B. Djurisic, Fabrication of bulk heterojunction photovoltaic devices using sublimable rhenium diimine complexes as photosensitizers., in: Z.H. Kafafi, P.A. Lane (Eds.), Proc. SPIE-The Int. Soc. Opt. Eng., 2004: pp. 168-175. doi:10.1117/12.558680.

[105] H.L. Wong, K.K.Y. Man, W.K. Chan, C.Y. Kwong, A.B. Djurišić, Efficient Bulk Heterojunction Photovoltaic Cells using Sublimable Transition Metal Complex as Photosensitizers, MRS Proc. 836 (2004) L5.19. doi:10.1557/PROC-836-L5.19.

[106] F. He, Y. Zhou, S. Liu, L. Tian, H. Xu, H. Zhang, B. Yang, Q. Dong, W. Tian, Y. Ma, J. Shen, Cruciform oligo(phenylenevinylene) with a bipyridine bridge: synthesis, its rhenium(i) complex and photovoltaic properties, Chem. Commun. (2008) 3912. doi:10.1039/b804995e.

[107] X. Yi, J. Zhao, W. Wu, D. Huang, S. Ji, J. Sun, Rhenium(i) tricarbonyl polypyridine complexes showing strong absorption of visible light and long-lived triplet excited states as a triplet photosensitizer for triplet-triplet annihilation upconversion, Dalt. Trans. 41 (2012) 8931. doi:10.1039/c2dt30804e.

[108] X. Yi, J. Zhao, J. Sun, S. Guo, H. Zhang, Visible light-absorbing rhenium( $\langle\operatorname{scp}\rangle i</ s c p\rangle$ ) tricarbonyl complexes as triplet photosensitizers in photooxidation and triplet-triplet annihilation upconversion, Dalt. Trans. 42 (2013) 2062-2074. doi:10.1039/C2DT32420B. 
[109] A. Capobianchi, M. Tucci, Ruthenium phthalocyanine thin films for photovoltaic applications, Thin Solid Films. 451-452 (2004) 33-36. doi:10.1016/j.tsf.2003.11.039.

[110] M.K.R. Fischer, I. López-Duarte, M.M. Wienk, M.V. Martínez-Díaz, R.A.J. Janssen, P. Bäuerle, T. Torres, Functionalized dendritic oligothiophenes: Ruthenium phthalocyanine complexes and their application in bulk heterojunction solar cells, J. Am. Chem. Soc. 131 (2009) 86698676. doi:10.1021/ja901537d.

[111] A. Colombo, C. Dragonetti, D. Roberto, R. Ugo, L. Falciola, S. Luzzati, D. Kotowski, A novel diruthenium acetylide donor complex as an unusual active material for bulk heterojunction solar cells, Organometallics. 30 (2011) 1279-1282. doi:10.1021/om100846e.

[112] Q. Liu, C.-L. Ho, N. Zhu, Y. Fu, Z. Xie, L. Wang, P.D. Harvey, W.-Y. Wong, Synthesis and photovoltaic properties of new ruthenium(II)-bis(aryleneethynylene) complexes, J. Organomet. Chem. 846 (2017) 277-286. doi:10.1016/j.jorganchem.2017.06.026.

[113] A. Bessette, M. Cibian, J.G. Ferreira, B.N. DiMarco, F. Bélanger, D. Désilets, G.J. Meyer, G.S. Hanan, Azadipyrromethene cyclometalation in neutral Ru " complexes: photosensitizers with extended near-infrared absorption for solar energy conversion applications, Dalt. Trans. 45 (2016) 10563-10576. doi:10.1039/C6DT00961A.

[114] C.M. Yang, C.H. Wu, H.H. Liao, K.Y. Lai, H.P. Cheng, S.F. Horng, H.F. Meng, J.T. Shy, Enhanced photovoltaic response of organic solar cell by singlet-to-triplet exciton conversion, Appl. Phys. Lett. 90 (2007) 133509. doi:10.1063/1.2716209.

[115] Z. Xu, B. Hu, J. Howe, Improvement of photovoltaic response based on enhancement of spinorbital coupling and triplet states in organic solar cells, J. Appl. Phys. 103 (2008) 43909. doi:10.1063/1.2885349.

[116] W.A. Luhman, R.J. Holmes, Enhanced exciton diffusion in an organic photovoltaic cell by energy transfer using a phosphorescent sensitizer, Appl. Phys. Lett. 94 (2009) 153304. doi:10.1063/1.3120566.

[117] G. Winroth, D. Podobinski, F. Cacialli, Dopant optimization for triplet harvesting in polymer photovoltaics, J. Appl. Phys. 110 (2011) 124504. doi:10.1063/1.3665688.

[118] J. Huang, J. Yu, Z. Guan, Y. Jiang, Improvement in open circuit voltage of organic solar cells by inserting a thin phosphorescent iridium complex layer, Appl. Phys. Lett. 97 (2010) 143301. doi:10.1063/1.3492838. 
[119] J. Yu, J. Huang, H. Lin, Y. Jiang, Exciton diffusion length analysis of mixed donor materials in organic solar cells by doping with phosphorescent iridium complex, J. Appl. Phys. 108 (2010) 113111. doi:10.1063/1.3514545.

[120] Z. Wang, F. Zhang, Effect of doping phosphorescent material and annealing treatment on the performance of polymer solar cells, Int. J. Photoenergy. 2013 (2013) 1-7. doi:10.1155/2013/273586.

[121] M.H. Yun, E. Lee, W. Lee, H. Choi, B.R. Lee, M.H. Song, J.-I. Hong, T.-H. Kwon, J.Y. Kim, Enhanced performance of polymer bulk heterojunction solar cells employing multifunctional iridium complexes, J. Mater. Chem. C. 2 (2014) 10195-10200. doi:10.1039/C4TC01222D.

[122] E.-P. Yao, Y.-J. Tsai, W.-C. Hsu, An investigation of organic photovoltaics improvement via extension of the exciton lifetime, Phys. Chem. Chem. Phys. 17 (2015) 5826-5831. doi:10.1039/C4CP05459H.

[123] M. Qian, R. Zhang, J. Hao, W. Zhang, Q. Zhang, J. Wang, Y. Tao, S. Chen, J. Fang, W. Huang, Dramatic enhancement of power conversion efficiency in polymer solar cells by conjugating very low ratio of triplet iridium complexes to PTB7, Adv. Mater. 27 (2015) 3546-3552. doi:10.1002/adma.201500730.

[124] H.-T. Kim, J.H. Seo, J.H. Ahn, M.-J. Baek, H.-D. Um, S. Lee, D.-H. Roh, J.-H. Yum, T.J. Shin, K. Seo, T.-H. Kwon, Customized Energy Down-Shift Using Iridium Complexes for Enhanced Performance of Polymer Solar Cells, ACS Energy Lett. 1 (2016) 991-999. doi:10.1021/acsenergylett.6b00518.

[125] P. Fan, Y. Zheng, D. Zheng, J. Yu, Improved efficiency of bulk heterojunction polymer solar cells by doping with iridium complex, Mater. Lett. 186 (2017) 161-164. doi:10.1016/j.matlet.2016.09.118.

[126] W. Lee, T.-H. Kwon, J. Kwon, J. Kim, C. Lee, J.-I. Hong, Effect of main ligands on organic photovoltaic performance of $\operatorname{Ir}($ iii) complexes, New J. Chem. 35 (2011) 2557. doi:10.1039/c1nj20446g.

[127] N. Wang, J. Yu, Y. Zheng, Z. Guan, Y. Jiang, Organic photovoltaic cells based on a mediumbandgap phosphorescent material and C 60, J. Phys. Chem. C. 116 (2012) 5887-5891. doi:10.1021/jp210245a.

[128] T.B. Fleetham, Z. Wang, J. Li, Exploring cyclometalated Ir complexes as donor materials for 
organic solar cells, Inorg. Chem. 52 (2013) 7338-7343. doi:10.1021/ic3023453.

[129] H. Zhen, Q. Hou, K. Li, Z. Ma, S. Fabiano, F. Gao, F. Zhang, Solution-processed bulkheterojunction organic solar cells employing Ir complexes as electron donors, J. Mater. Chem. A. 2 (2014) 12390-12396. doi:10.1039/C4TA01526F.

[130] Y. Shao, Y. Yang, Efficient organic heterojunction photovoltaic cells based on triplet materials, Adv. Mater. 17 (2005) 2841-2844. doi:10.1002/adma.200501297.

[131] D.B. Papkovsky, New oxygen sensors and their application to biosensing, Sensors Actuators B. Chem. 29 (1995) 213-218. doi:10.1016/0925-4005(95)01685-6.

[132] B.P. Rand, S. Schols, D. Cheyns, H. Gommans, C. Girotto, J. Genoe, P. Heremans, J. Poortmans, Organic solar cells with sensitized phosphorescent absorbing layers, Org. Electron. Physics, Mater. Appl. 10 (2009) 1015-1019. doi:10.1016/j.orgel.2009.04.011.

[133] F. Guo, K. Ogawa, Y.-G. Kim, E.O. Danilov, F.N. Castellano, J.R. Reynolds, K.S. Schanze, A fulleropyrrolidine end-capped platinum-acetylide triad: the mechanism of photoinduced charge transfer in organometallic photovoltaic cells, Phys. Chem. Chem. Phys. 9 (2007) 2724. doi:10.1039/b700379j.

[134] F. Guo, Y.-G. Kim, J.R. Reynolds, K.S. Schanze, Platinum-acetylide polymer based solar cells: involvement of the triplet state for energy conversion, Chem. Commun. (2006) 1887-1889. doi:10.1039/B516086C.

[135] M.D. Perez, C. Borek, P.I. Djurovich, E.I. Mayo, R.R. Lunt, S.R. Forrest, M.E. Thompson, Organic photovoltaics using tetraphenylbenzoporphyrin complexes as donor layers, Adv. Mater. 21 (2009) 1517-1520. doi:10.1002/adma.200802683.

[136] M. Dolores Perez, C. Borek, S.R. Forrest, M.E. Thompson, Molecular and morphological influences on the open circuit voltages of organic photovoltaic devices, J. Am. Chem. Soc. 131 (2009) 9281-9286. doi:10.1021/ja9007722.

[137] S.T. Roberts, C.W. Schlenker, V. Barlier, R.E. McAnally, Y. Zhang, J.N. Mastron, M.E. Thompson, S.E. Bradforth, Observation of triplet exciton formation in a platinum-sensitized organic photovoltaic device, J. Phys. Chem. Lett. 2 (2011) 48-54. doi:10.1021/jz101554m.

[138] Y. Li, R. Mastria, K. Li, A. Fiore, Y. Wang, R. Cingolani, L. Manna, G. Gigli, Improved photovoltaic performance of bilayer heterojunction photovoltaic cells by triplet materials and tetrapod-shaped colloidal nanocrystals doping, Appl. Phys. Lett. 95 (2009) 43101. 
doi:10.1063/1.3186074.

[139] I. Kim, H.M. Haverinen, Z. Wang, S. Madakuni, Y. Kim, J. Li, G.E. Jabbour, Efficient organic solar cells based on planar metallophthalocyanines, Chem. Mater. 21 (2009) 4256-4260. doi:10.1021/cm901320p.

[140] I. Kim, H.M. Haverinen, J. Li, G.E. Jabbour, Enhanced power conversion efficiency of p-i-n type organic solar cells by employing a $p$-layer of palladium phthalocyanine, Appl. Phys. Lett. 97 (2010) 203301. doi:10.1063/1.3507387.

[141] G.P. Kushto, A.J. Makinen, P.A. Lane, Organic Photovoltaic Cells Using Group 10 Metallophthalocyanine Electron Donors, IEEE J. Sel. Top. Quantum Electron. 16 (2010) 1552 1559. doi:10.1109/JSTQE.2010.2052354

[142] X. Zhao, C. Piliego, B. Kim, D.A. Poulsen, B. Ma, D.A. Unruh, J.M.J. Fréchet, Solutionprocessable crystalline platinum-acetylide oligomers with broadband absorption for photovoltaic cells, Chem. Mater. 22 (2010) 2325-2332. doi:10.1021/cm903329a.

[143] L. Li, W.C. Chow, W.Y. Wong, C.H. Chui, R.S.M. Wong, Synthesis, characterization and photovoltaic behavior of platinum acetylide polymers with electron-deficient 9,10anthraquinone moiety, J. Organomet. Chem. 696 (2011) 1189-1197. doi:10.1016/j.jorganchem.2010.08.044.

[144] K.H. Low, Z.X. Xu, H.F. Xiang, S.S.Y. Chui, V.A.L. Roy, C.M. Che, Bis(5,7-dimethyl-8hydroxyquinolinato)platinum(II) complex for efficient organic heterojunction solar cells, Chem. - An Asian J. 6 (2011) 3223-3229. doi:10.1002/asia.201100450.

[145] F.R. Dai, H.M. Zhan, Q. Liu, Y.Y. Fu, J.H. Li, Q.W. Wang, Z. Xie, L. Wang, F. Yan, W.Y. Wong, Platinum (II)-bis (aryleneethynylene) complexes for solution-processible molecular bulk heterojunction solar cells, Chem. - A Eur. J. 18 (2012) 1502-1511. doi:10.1002/chem.201102598.

[146] H. Wang, M. Chen, B. Jiang, W. Tong, Q. Qian, K. Lin, F. Liu, Solution-Processable PlatinumAcetylide-based Small Molecular Bulk Heterojunction Solar Cells, Chinese J. Chem. 33 (2015) 917-924. doi:10.1002/cjoc.201500260.

[147] Y. Zhang, S. Zhang, L. Yao, L. Qin, L. Nian, Z. Xie, B. Yang, L. Liu, Y. Ma, Triphenylaminesubstituted metalloporphyrins for solution-processed bulk heterojunction solar cells: The effect of the central metal ion on device performance, Eur. J. Inorg. Chem. 2014 (2014) 4852- 
4857. doi:10.1002/ejic.201402427.

[148] S. Fu, X. Zhu, G. Zhou, W.Y. Wong, C. Ye, W.K. Wong, Z. Li, Synthesis, structures and optical power limiting of some transition metal and lanthanide monoporphyrinate complexes containing electron-rich diphenylamino substituents, Eur. J. Inorg. Chem. 2007 (2007) 20042013. doi:10.1002/ejic.200601190.

[149] W. He, M.Y. Livshits, D.A. Dickie, J. Yang, R. Quinnett, J.J. Rack, Q. Wu, Y. Qin, A "roller-wheel" Pt-containing small molecule that outperforms its polymer analogs in organic solar cells, Chem. Sci. 7 (2016) 5798-5804. doi:10.1039/C6SC00513F.

[150] S.L. Lai, L. Wang, C. Yang, M.Y. Chan, X. Guan, C.C. Kwok, C.M. Che, Gold(III) corroles for high performance organic solar cells, Adv. Funct. Mater. 24 (2014) 4655-4665. doi:10.1002/adfm.201400082.

[151] Q. Wang, Y. Li, X. Yan, M. Rathi, M. Ropp, D. Galipeau, J. Jiang, Organic photovoltaic cells made from sandwich-type rare earth phthalocyaninato double and triple deckers, Appl. Phys. Lett. 93 (2008) 73303. doi:10.1063/1.2966151.

[152] Y. Li, Y. Bian, M. Yan, P.S. Thapaliya, D. Johns, X. Yan, D. Galipeau, J. Jiang, Mixed (porphyrinato)(phthalocyaninato) rare-earth(III) double-decker complexes for broadband light harvesting organic solar cells, J. Mater. Chem. 21 (2011) 11131. doi:10.1039/c1jm11246e.

[153] R. Andernach, H. Utzat, S.D. Dimitrov, I. McCulloch, M. Heeney, J.R. Durrant, H. Bronstein, Synthesis and Exciton Dynamics of Triplet Sensitized Conjugated Polymers, J. Am. Chem. Soc. 137 (2015) 10383-10390. doi:10.1021/jacs.5b06223. 


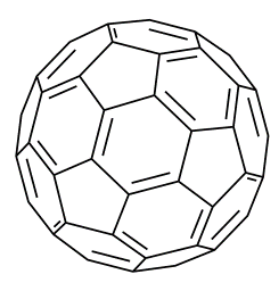

$\mathrm{C}_{60}$

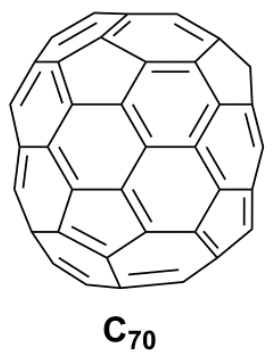

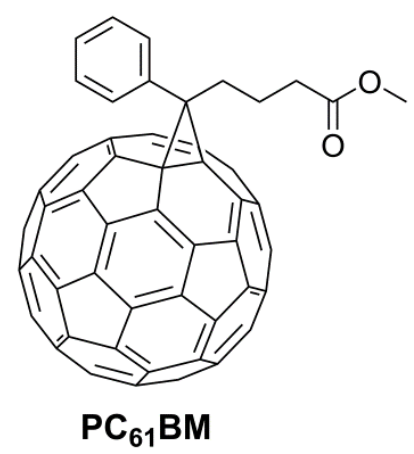

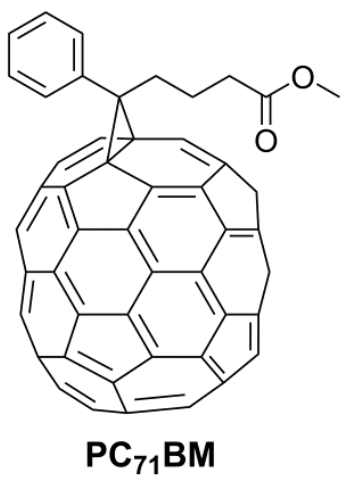

Figure 1 

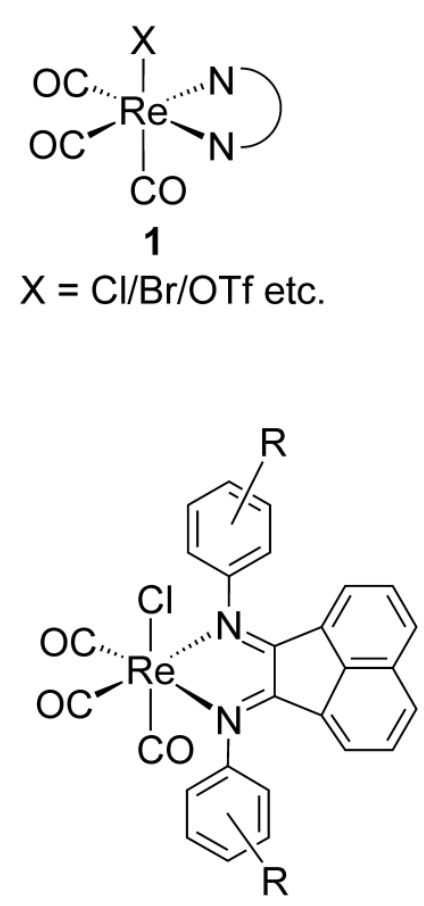

3a-h<smiles>[R]c1ccc(N2C(C)=C(C)N(c3ccc([R])cc3)[P+](C)(C(C)=O)OC2(C)C)cc1</smiles>
a $\mathrm{R}=4-\mathrm{H}$
b $\mathrm{R}=4-\mathrm{OMe}$
c $\mathrm{R}=4-\mathrm{Me}$
d $\mathrm{R}=4-\mathrm{Br}$
e $\mathrm{R}=4-\mathrm{Cl}$
f $\mathrm{R}=3-\mathrm{CF}_{3}$
g $\mathrm{R}=4-\mathrm{CF}_{3}$
h $\mathrm{R}=4-\mathrm{F}$

a $R=H$
b $R=M e$
c $R=O M e$
d $R=F$
e $R=\mathrm{NPh}_{2}$

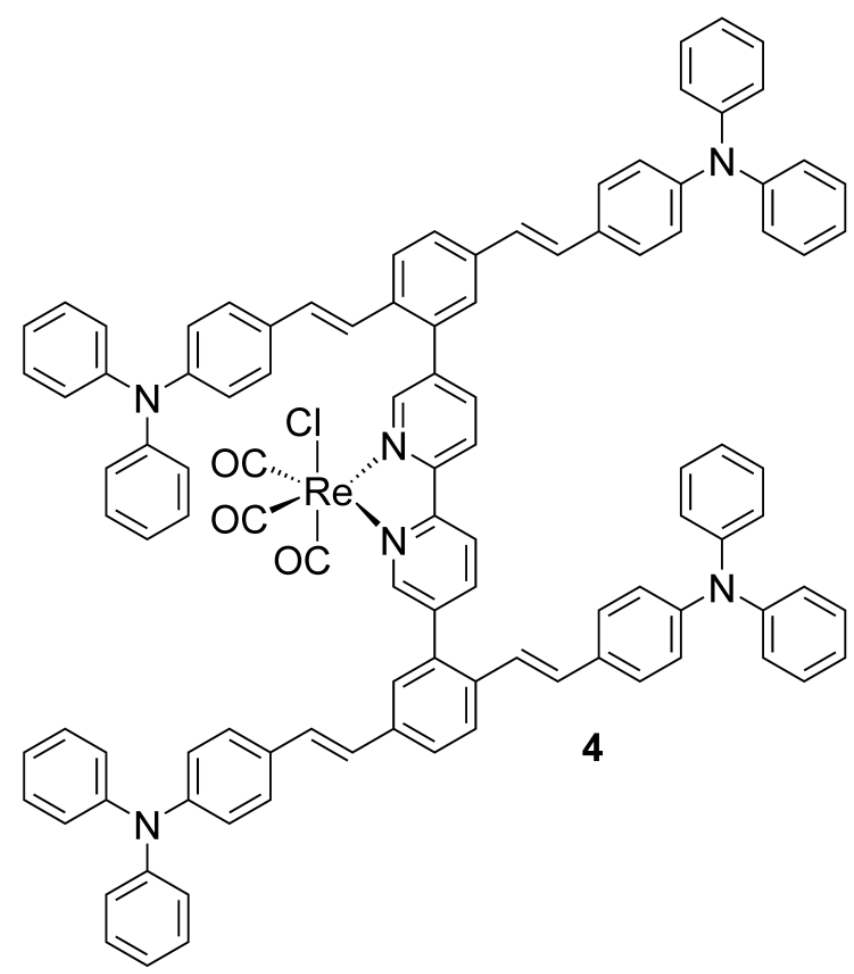

Figure 2 


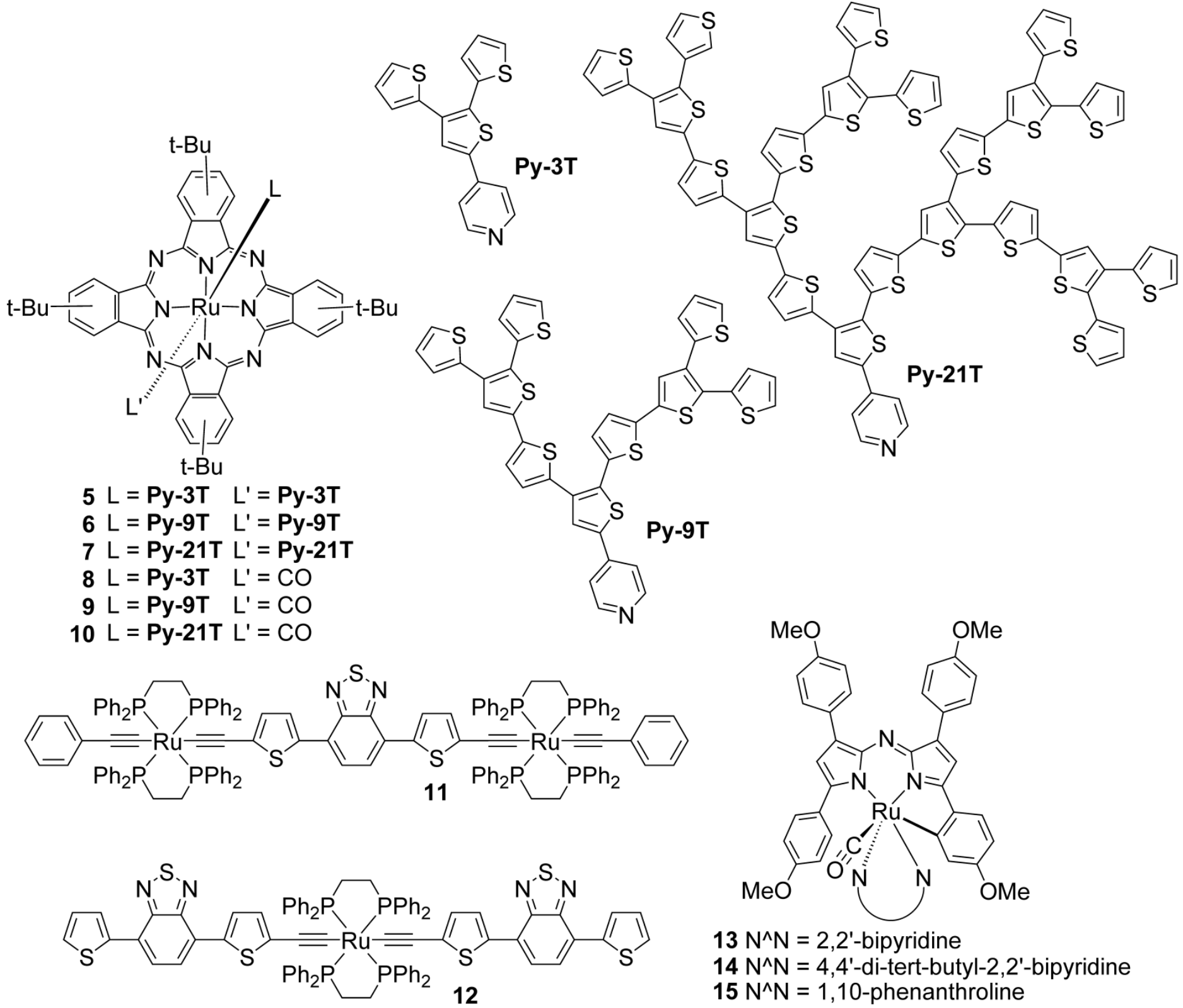

Figure 3 

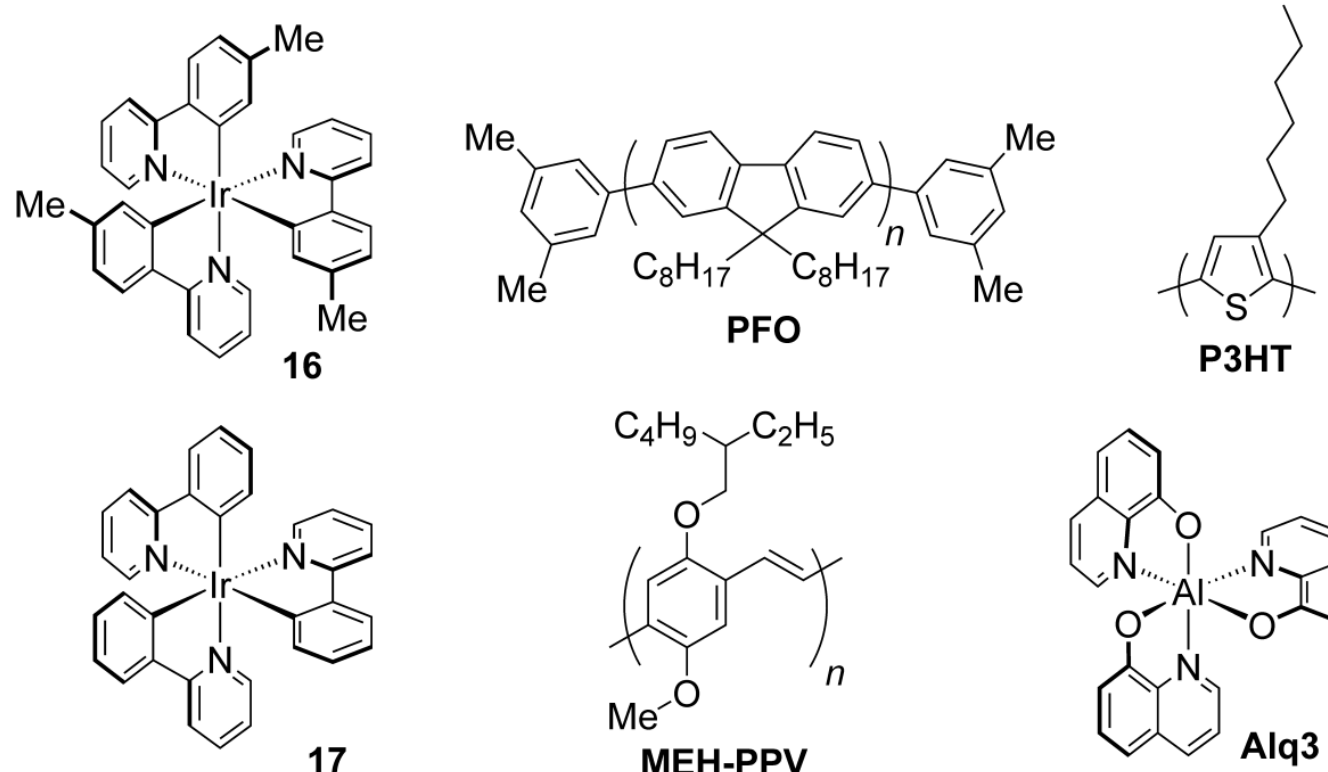

MEH-PPV
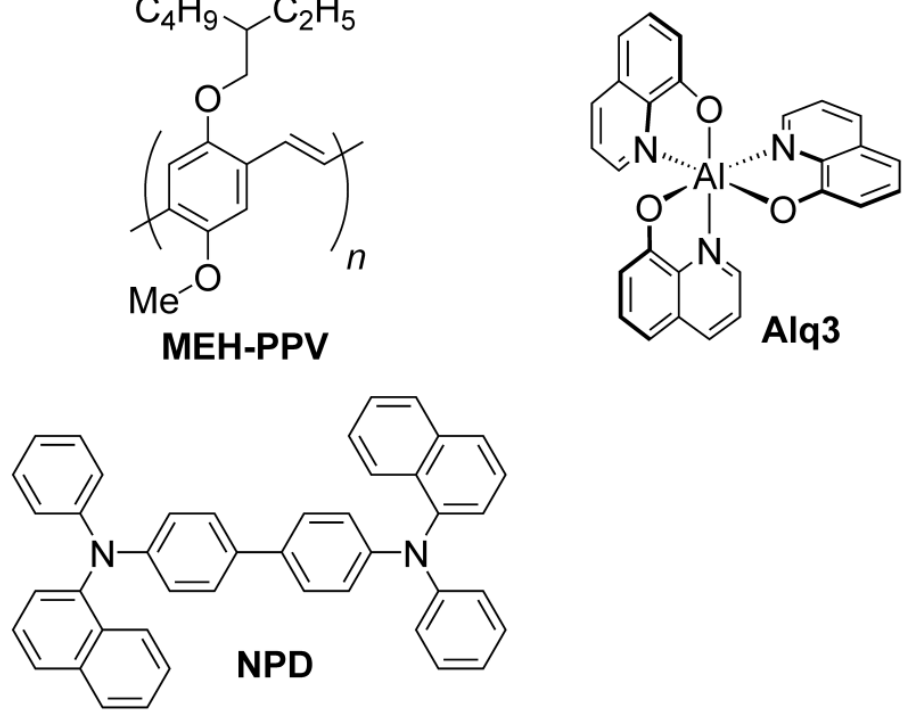

Figure 4 

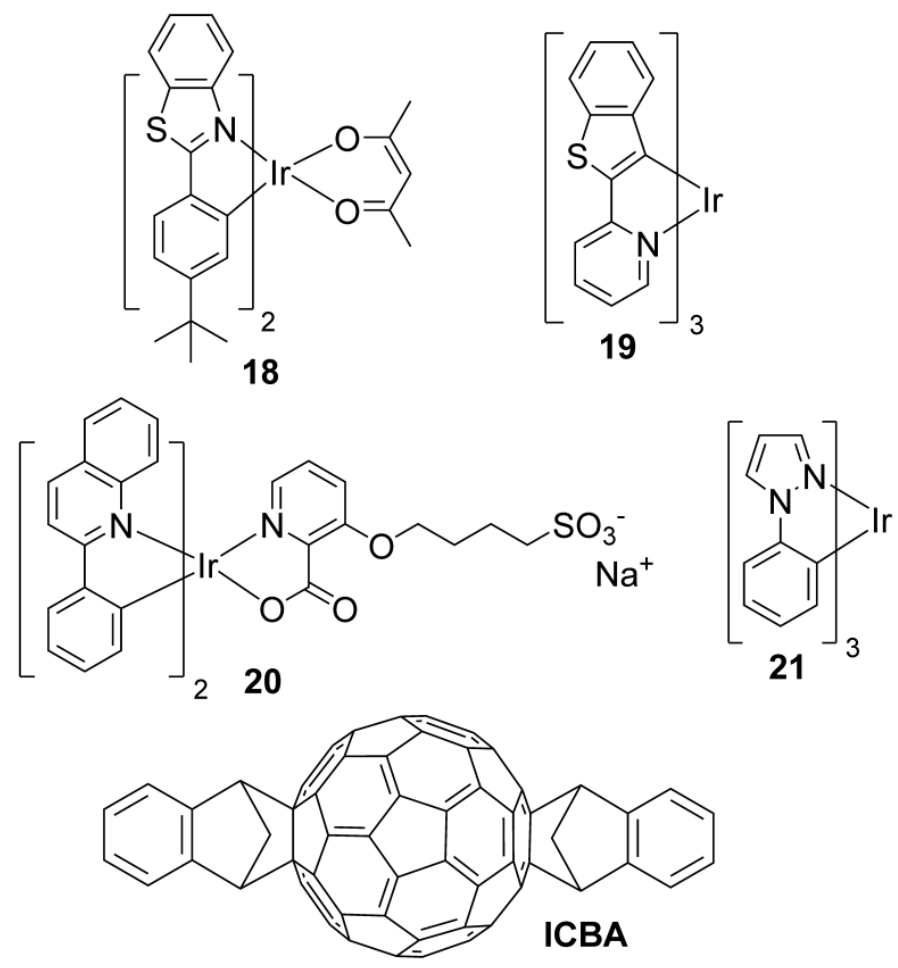

Figure 5 

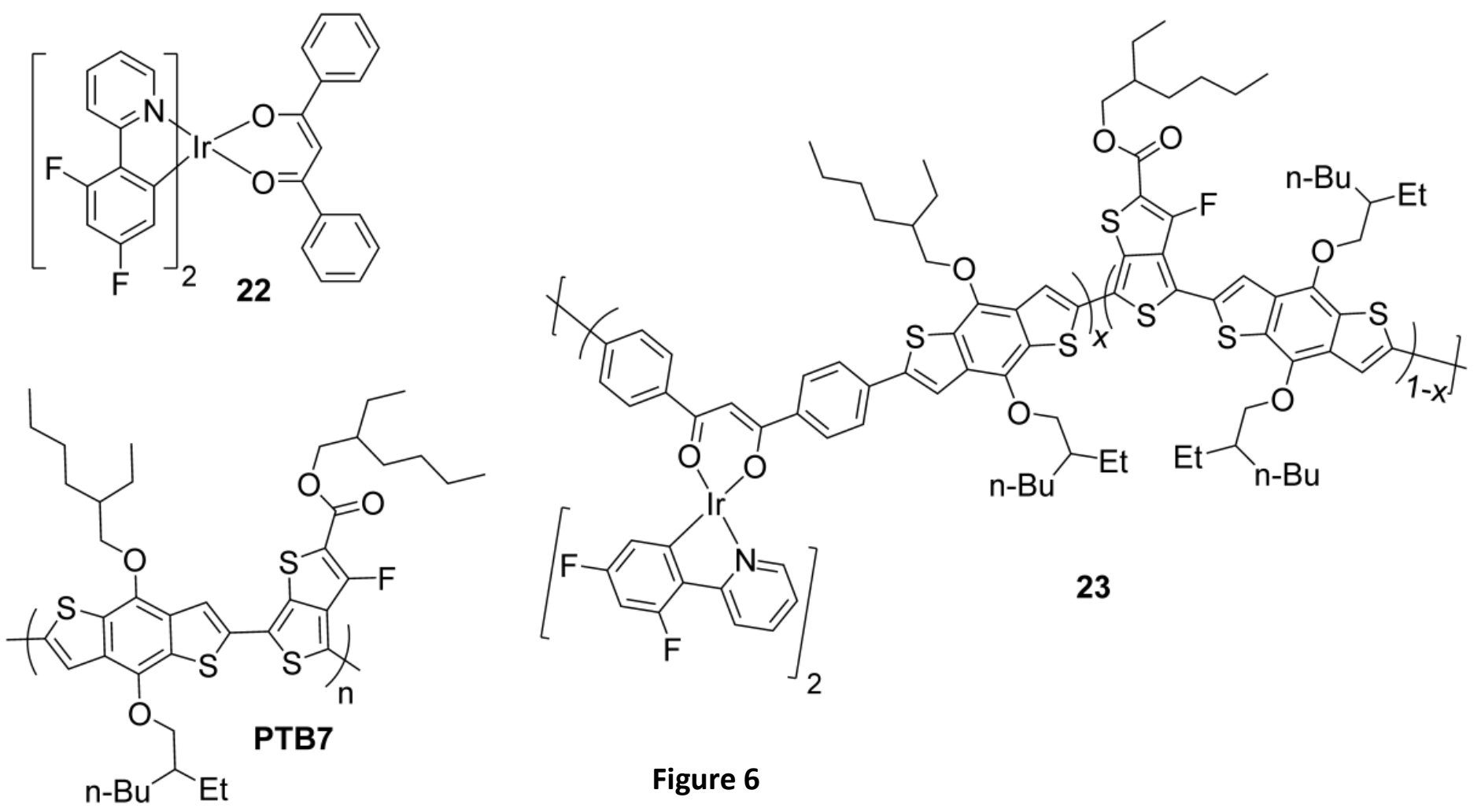

Figure 6 

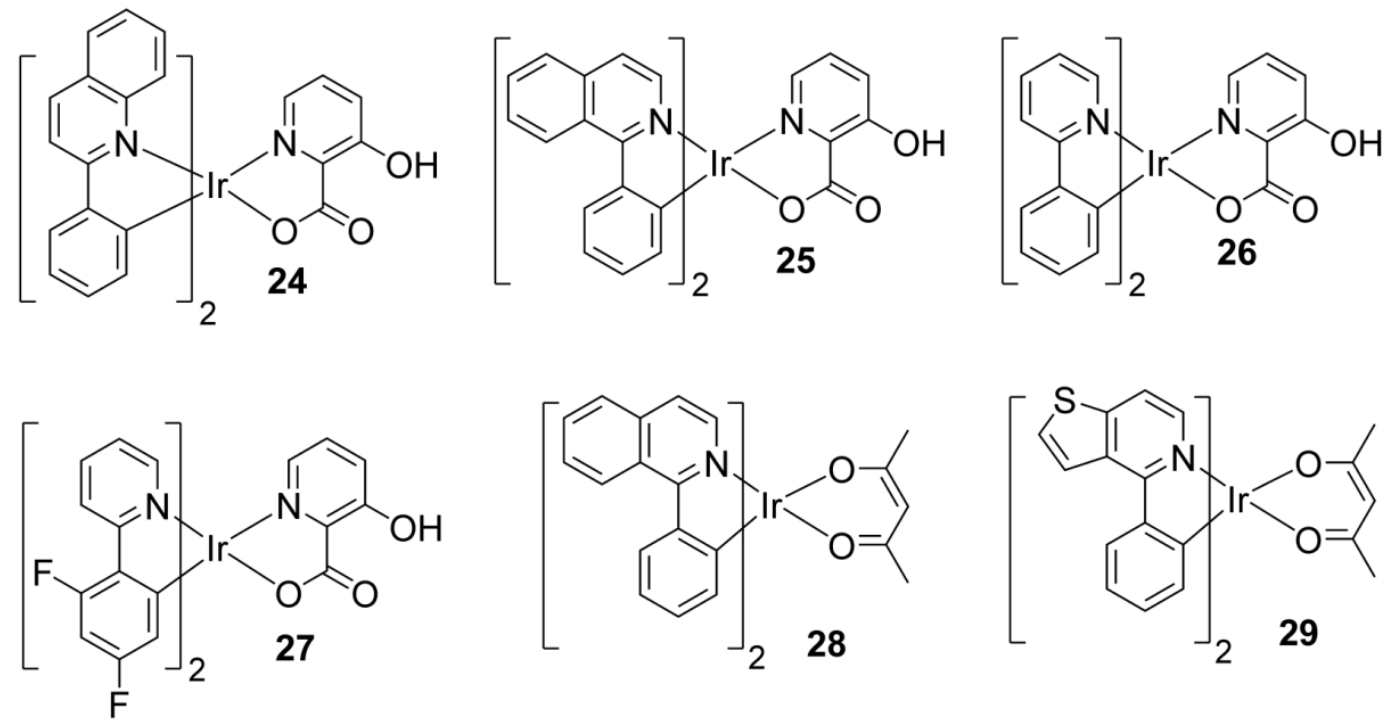

Figure 7 


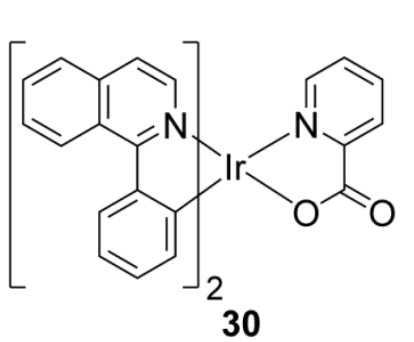

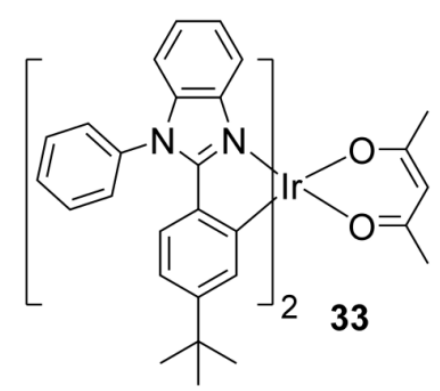
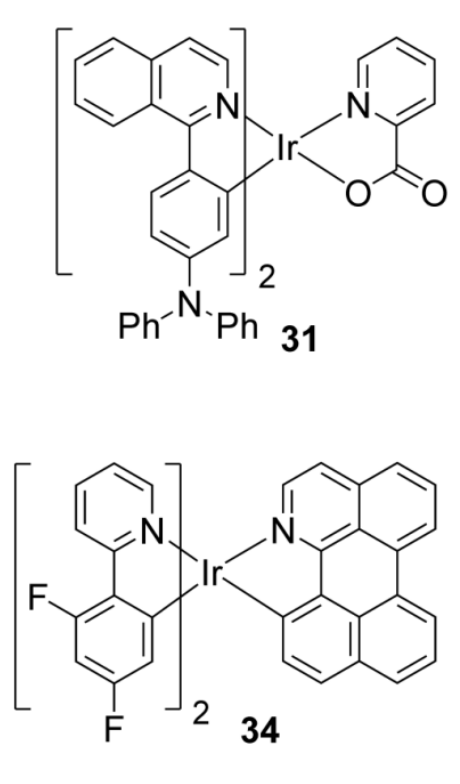
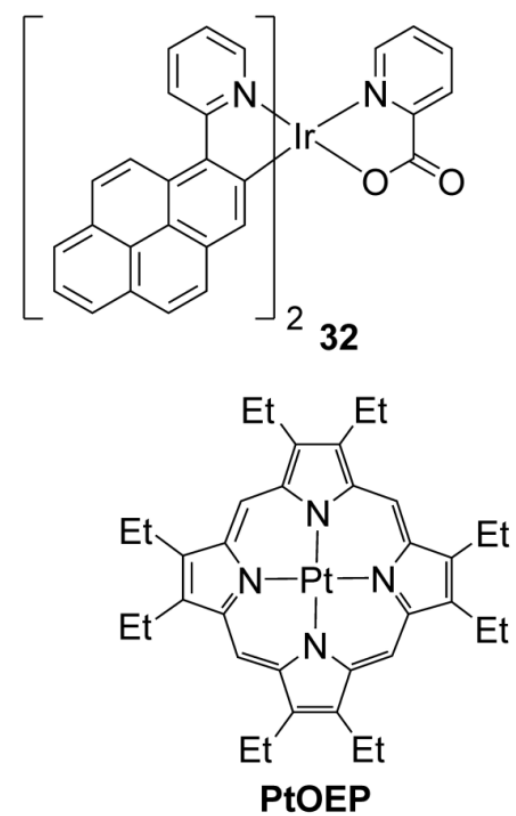

Figure 8 


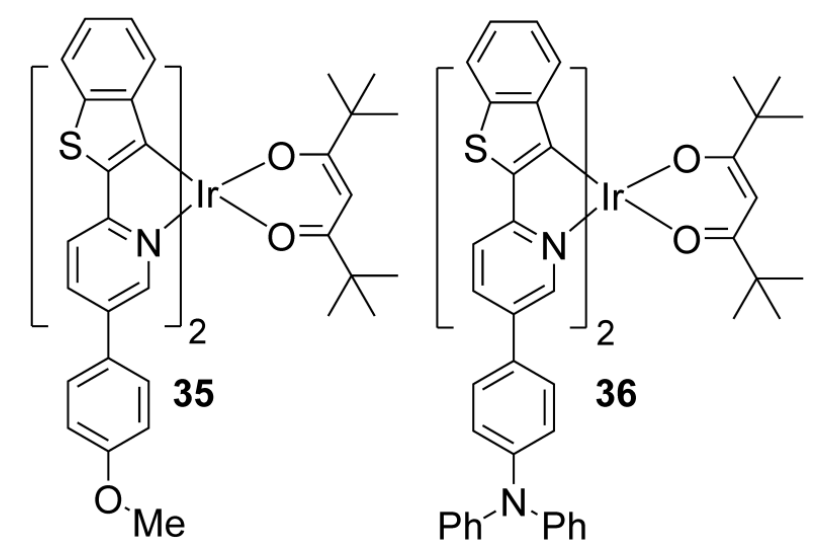

Figure 9 

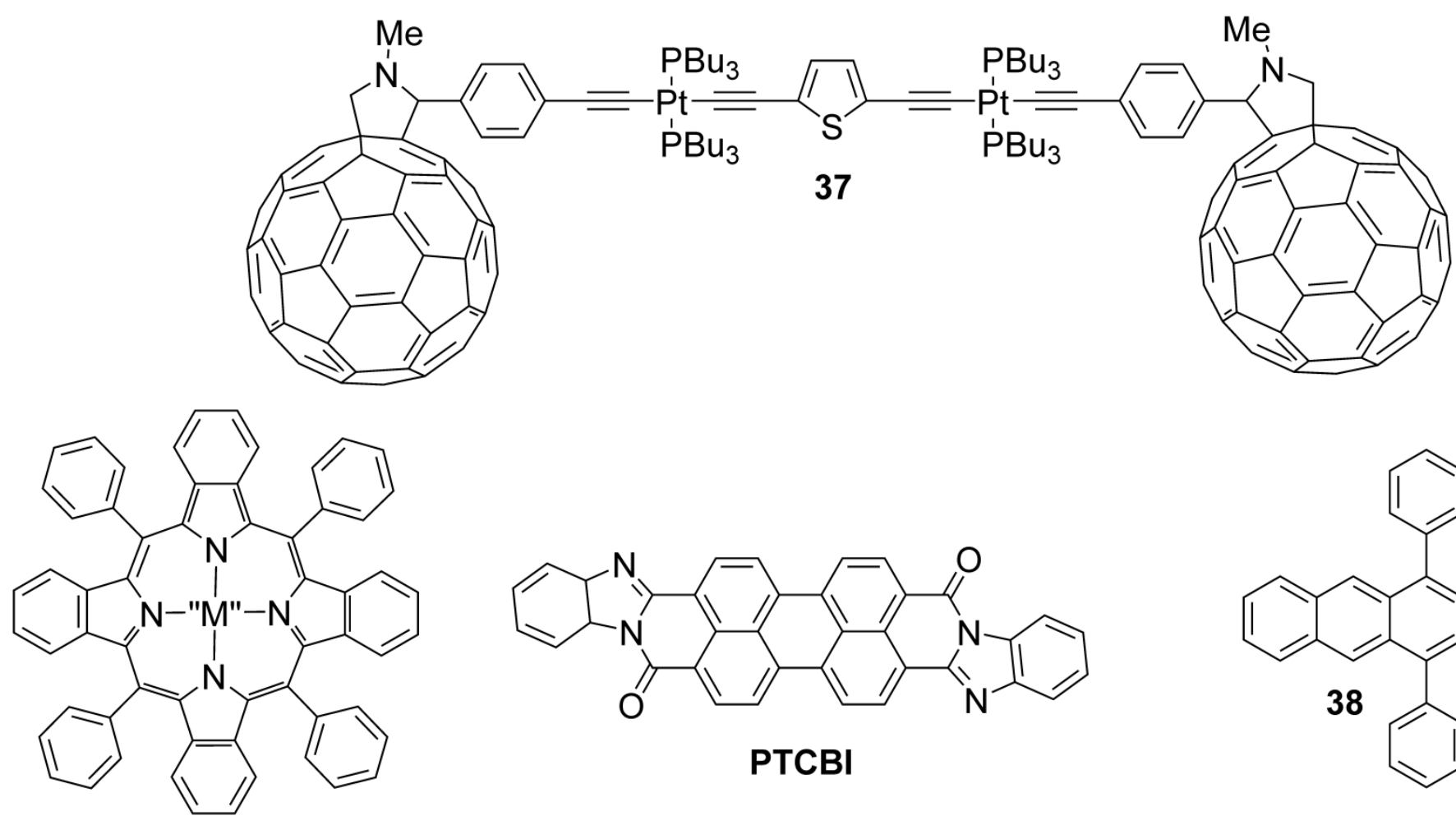

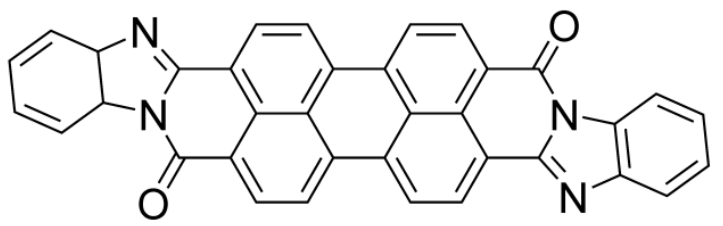

PTCBI

"M"TPBP $\mathrm{M}=\mathrm{Pd}, \mathrm{Pt}$

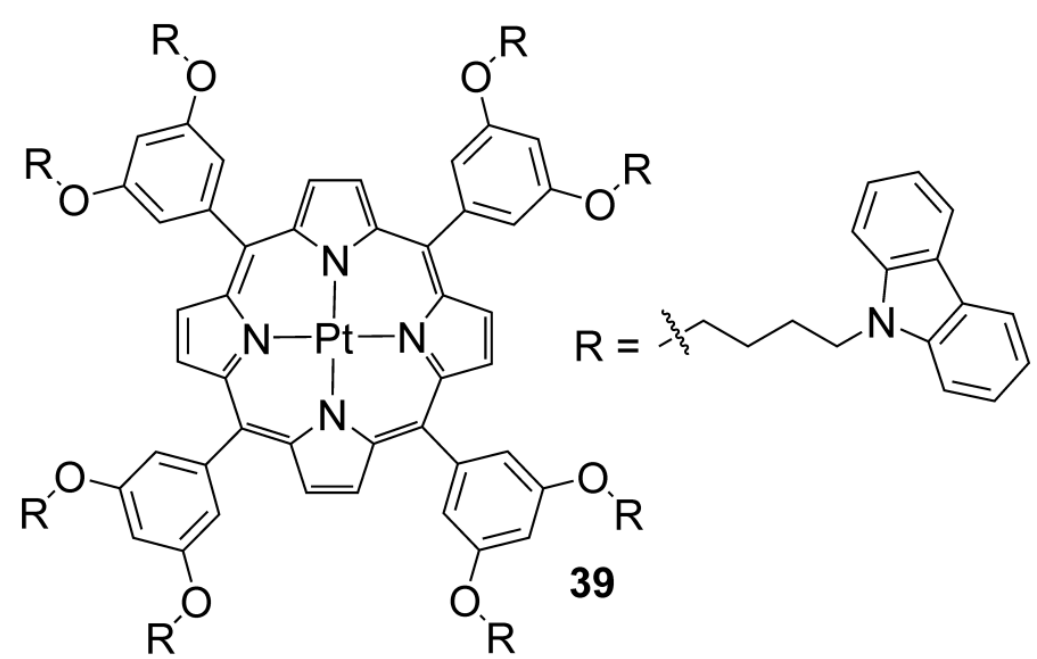

Figure 10 

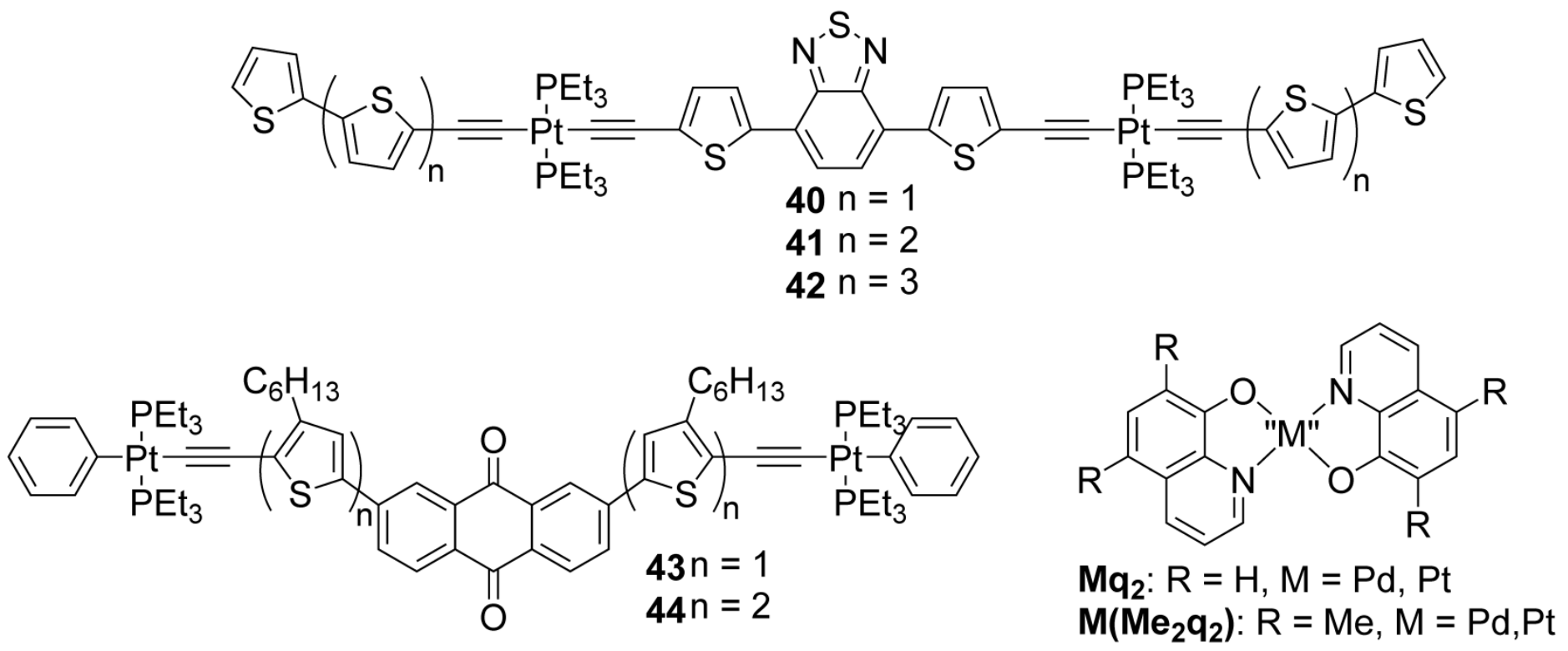

Figure 11 

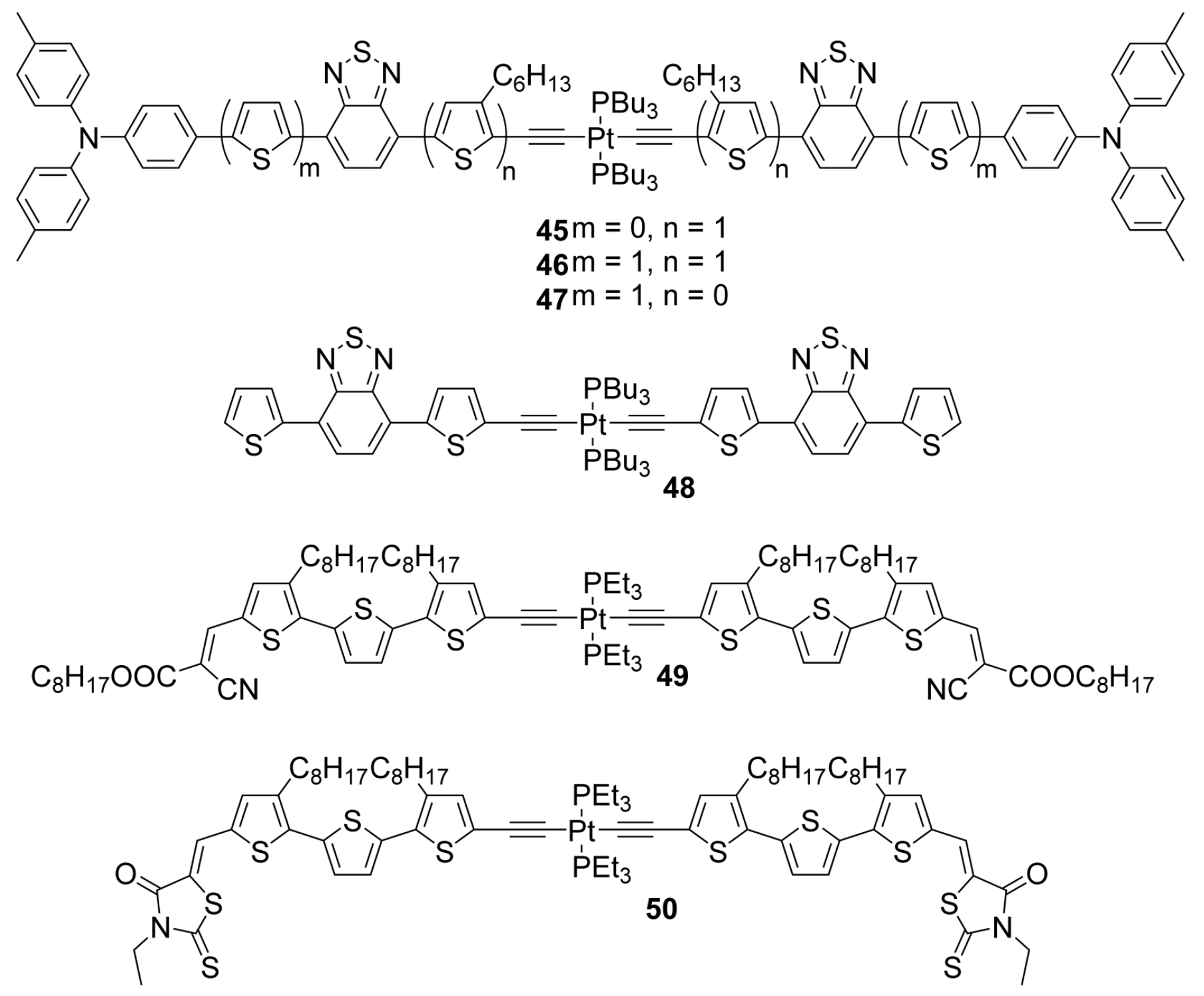

Figure 12 

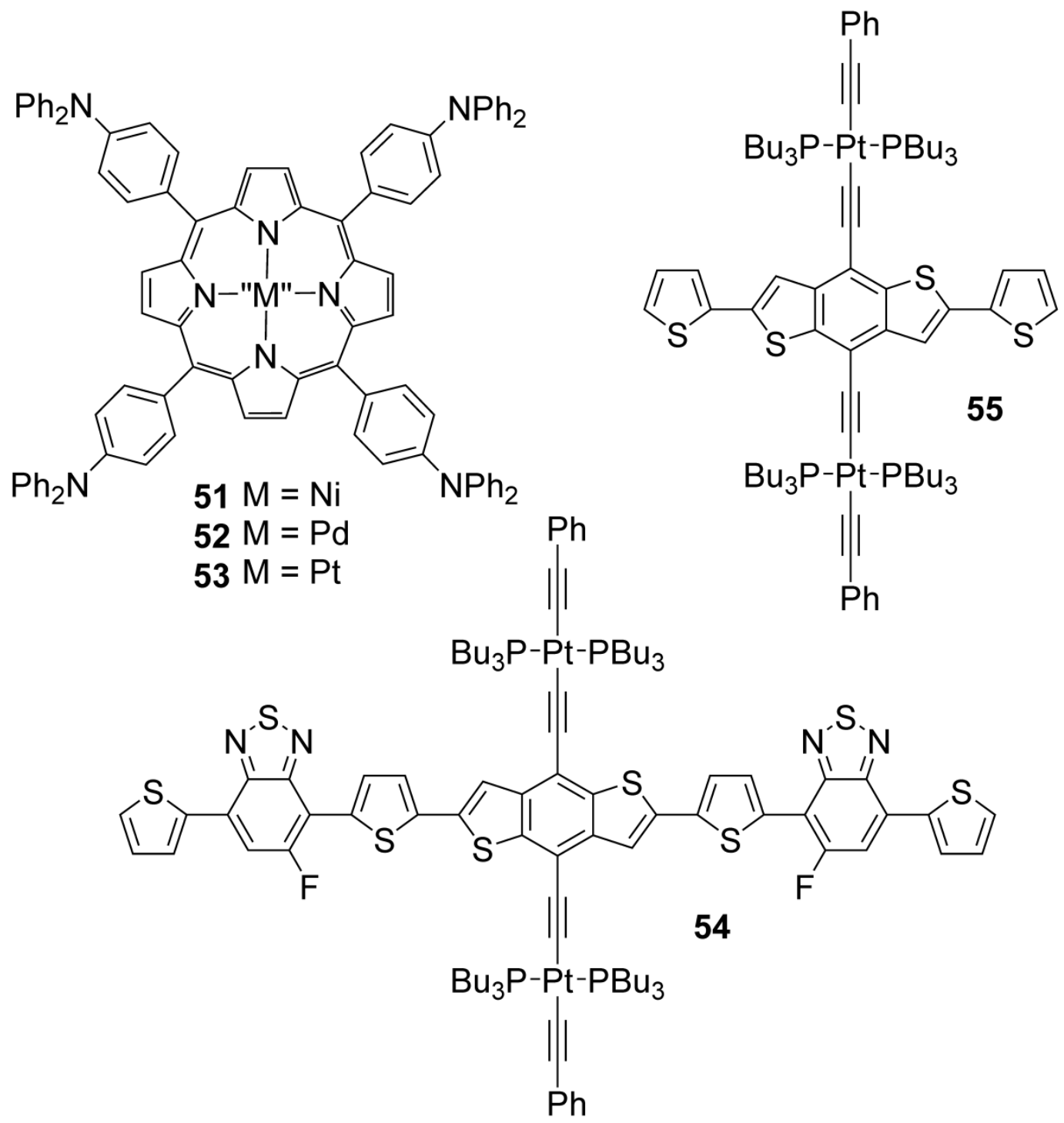

Figure 13 


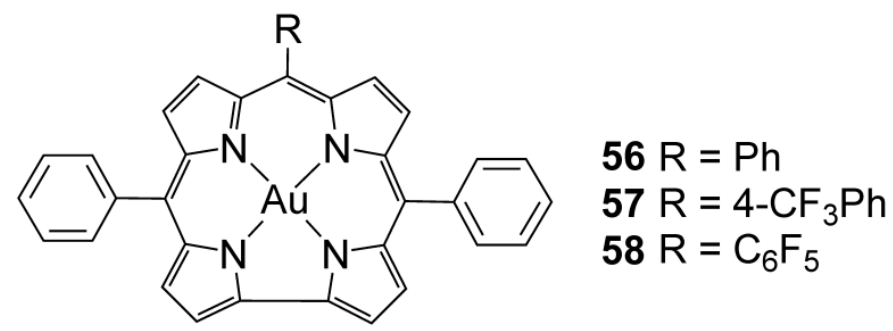

Figure 14 


\begin{tabular}{lllll}
\hline Donor:Acceptor & $\boldsymbol{V}_{\text {oc }}(\mathbf{V})$ & $\boldsymbol{J}_{\text {sc }}\left(\mathbf{m A ~ c m}^{-2}\right)$ & $\mathbf{F F}$ & $\boldsymbol{\eta}(\%)$ \\
\hline 5: $\mathrm{PC}_{61} \mathrm{BM}$ & 0.55 & 5.1 & 0.37 & 1.0 \\
8: $\mathrm{PC} \mathrm{C}_{61} \mathrm{BM}$ & 0.48 & 4.5 & 0.37 & 1.0 \\
5: $\mathrm{PC}_{71} \mathrm{BM}$ & 0.55 & 7.1 & 0.38 & 1.5 \\
8: $\mathrm{PC}_{71} \mathrm{BM}$ & 0.56 & 8.3 & 0.34 & 1.6 \\
\hline
\end{tabular}

Table 1 
a)

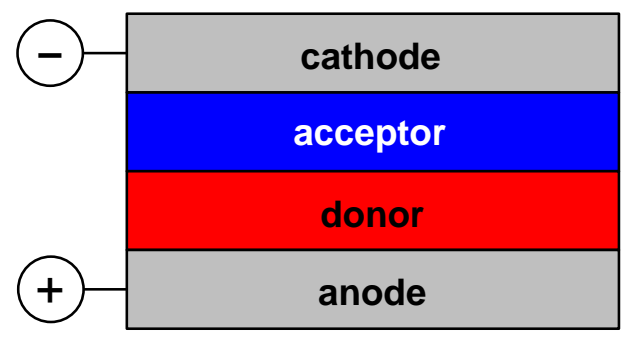

b)
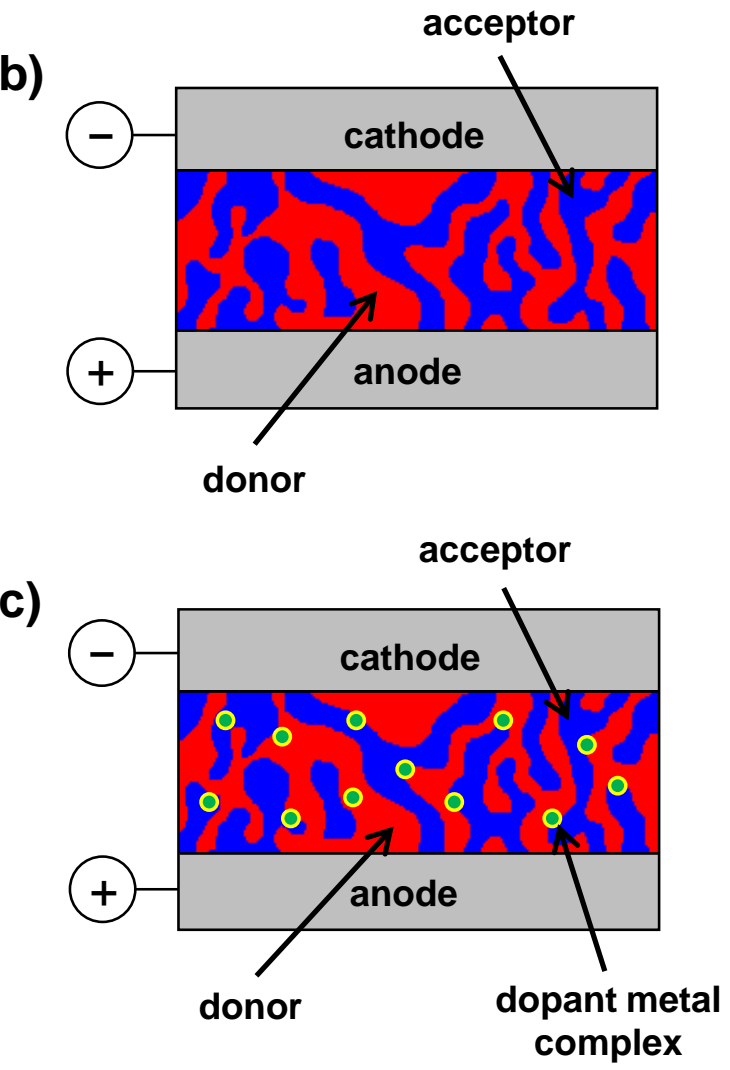


\section{Step 1:}

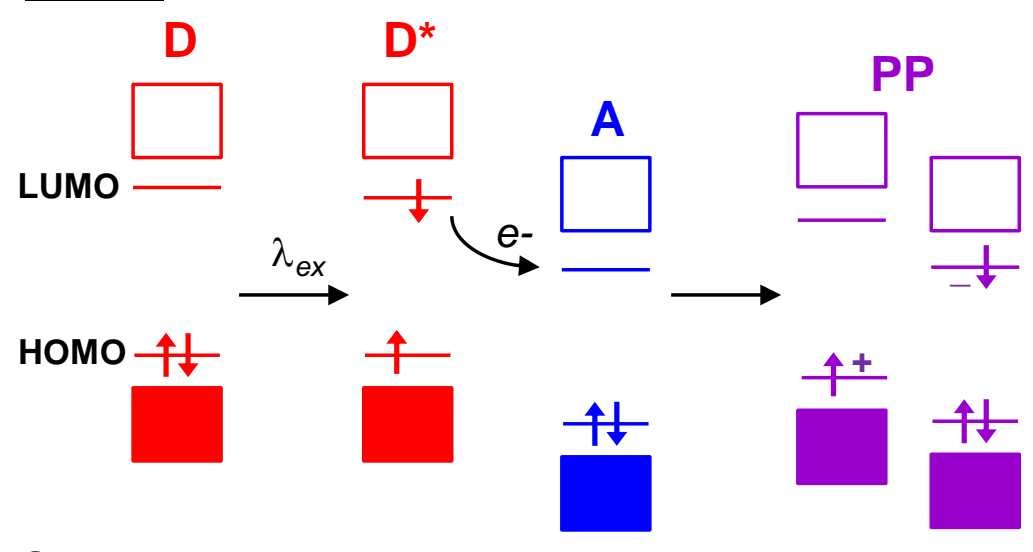

\section{Step 2:}

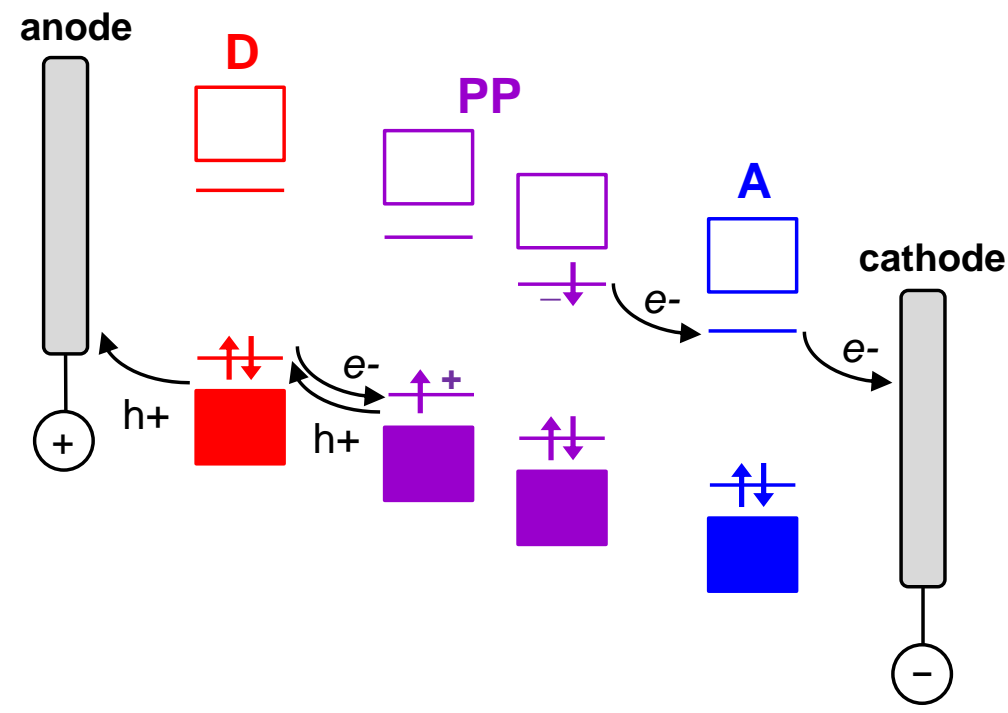




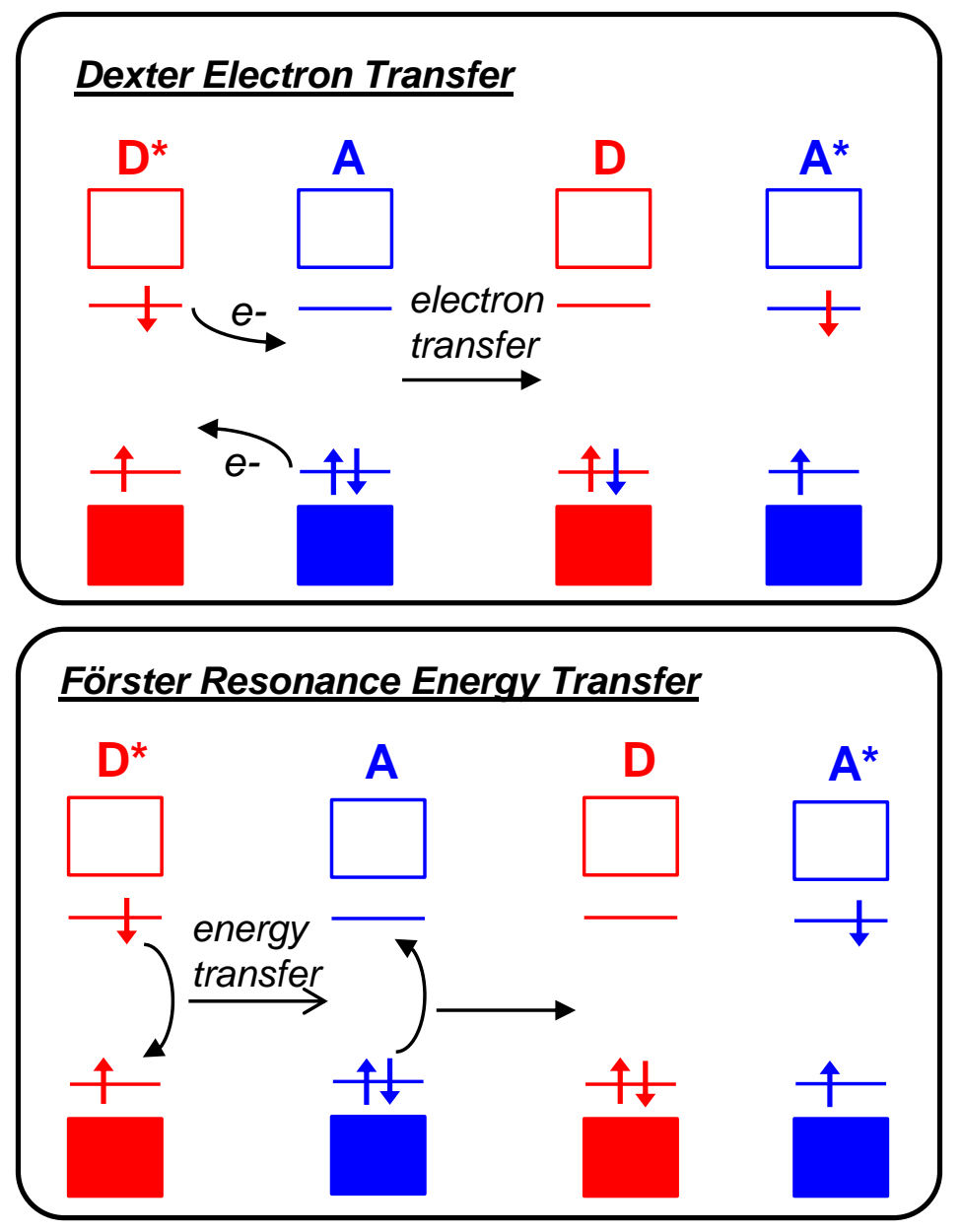




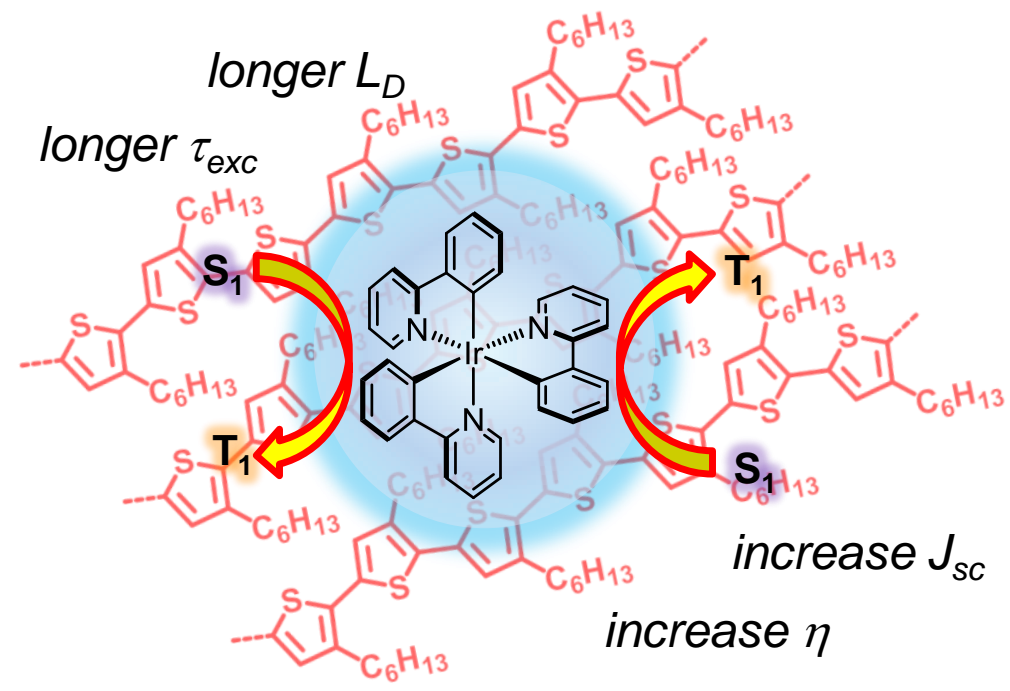




\section{Graphical abstract - synopsis}

Phosphorescent metal complexes can act as triplet sensitizers in organic heterojunction solar cells. Energy transfer and spin-orbit coupling processes between the phosphor and the organic matrix greatly increases the number of triplet excitons formed upon photoexcitation which can contribute to significant improvements in device efficiency. 